Mary Jane P. Spink 1

\title{
Trópicos do discurso sobre risco: risco-aventura como metáfora na modernidade tardia
}

\author{
Tropics of risk discourse: risk-adventure \\ as a metaphor in late modernity
}

1 Programa de Estudos Pós-Graduados em Psicologia Social, Pontifícia Universidade Católica de São Paulo. Rua Monte Al egre 984, São Paulo, SP 05014-091, Brasil. mjspink@pucsp.br
Abstract This article discusses new uses of interpretative repertoires of risk, especially those related to adventure. The author argues that the language of risk as adventure has multiple uses, as both a hedge against de-traditional izing processes typical of late modernity and a figure of speech for new sensitivities stemming from the imperative of coping with the imponderability and volatility of modern risks. The article begins with an overview of the historical meanings of risk, seeking to argue that, as language in use, risk is a useful vantage point for understanding the transformations currently under way in the forms of social control, suggesting that we are experiencing a transition from disciplinary society, typical of classic modernity, to risk society. The discussion then focuses on recent transformations in images of risk, with special emphasis on the trend to use risk-adventure as a metaphor for late modernity.

Key words Risk; Risk-Adventure; Reflexive Modernization; Risk Language

Resumo Este artigo tem como objetivo situar as novas modali dades de uso dos repertórios interpretati vos sobre risco, especialmente no que se refere à perspectiva da aventura. Propõe que, como aventura, a linguagem do risco cumpre atualmente funções múltiplas, sendo tanto um anteparo aos processos de destradi cionalização típi cos da modernidade tardia, como uma figura de linguagem utilizada para falar de novas sensi bilidades decorrentes do imperativo de enfrentar a imponderabilidade e volatilidade dos riscos modernos. Inicia com uma visão panorâmica dos sentidos históricos do risco buscando argumentar que a noção, entendi da na perspectiva da linguagem em uso, permite explorar as mudanças que vêm ocorrendo nas formas de controle social que nos possibilitam falar de uma transi ção da sociedade disciplinar, formação típica da modernidade clássica, para a sociedade de risco, formação emergente na modernidade tardia. Final iza apontando para as transformações que vêm ocorrendo nas imagens sobre ri sco, buscando destacar o uso crescente do risco-aventura como metáfora da modernidade tardia..

Palavras-chave Risco; Aventura; Modernidade Reflexiva; Linguagem do Risco 
Este texto tem o duplo objetivo de síntese e de reposicionamento frente à questão do risco na modernidade tardia. Como síntese, visa sistematizar as reflexões e resultados das pesquisas sobre risco por nós desenvolvidas desde 1997 (Spink, 1997, 1998, 1999). Como reposicionamento, pretende argumentar a favor da existência, hoje, de novas modalidades de uso dos repertórios interpretativos sobre risco. Proporemos, mais especificamente, que o risco, visto na perspectiva da aventura, cumpre atualmente funções múltiplas, sendo tanto um anteparo aos processos de destradicionalização típicos da modernidade tardia, como uma figura de linguagem utilizada para falar de novas sensibilidades decorrentes do imperativo de enfrentar a imponderabilidade e volatilidade dos riscos modernos.

Começaremos traçando uma visão panorâmica dos sentidos históricos de risco. Apoiando-nos nas teorizações de Hayden White (1994), buscaremos mais especificamente traçar o enredo arquetípico dos trópicos do discurso sobre risco. Pretendemos, por meio dessa panorâmica, argumentar que a noção de risco, entendida na perspectiva da linguagem em uso, permite explorar as mudanças que vêm ocorrendo nas formas de controle social que nos possibilitam falar de uma transição da sociedade disciplinar, formação típica da modernidade clássica, para a sociedade de risco, formação emergente na modernidade tardia.

Com essa contextualização como base, o cerne do nosso argumento propõe que estamos vivendo formas variadas de destradicionalização do risco que se fazem visíveis não apenas na multiplicidade de novas modalidades de aventura, mas também no uso metafórico do risco-aventura para referir-se sobretudo à imponderabilidade e volatilidade dos riscos manufaturados.

Antes, porém, são necessários alguns esclarecimentos conceituais. Ao utilizar o termo risco-aventura estamos nos referindo, apenas parcialmente, às novas modalidades de aventura e aos novos usos de antigas modalidades de jogos de vertigem. Optamos pelo termo composto risco-aventura, para enfatizar um deslocamento importante dos sentidos modernos do risco que recuperam a aventura como dimensão positivada da gestão dos riscos.

Os teóricos do risco, como Gary Machlis \& Eugene Rosa (1990), buscam incorporar essa dimensão em seus esquemas tipificadores sob a denominação de "risco desejado". O risco desejado, segundo a definição dada por esses autores, refere-se às "atividades ou eventos que têm incertezas quanto aos resultados ou conse- qüências, e em queas incertezas são componentes essenciais e propositais do comportamento" (Machlis \& Rosa, 1990:162). Acatam, assim, a impossibilidade de compreender risco apenas na perspectiva racionalizadora da análise de riscos, entendida como a triangulação entre cálculo, percepção e gerenciamento dos riscos.

Faz-se necessário esclarecer também, que as pesquisas que vêm sendo por nós desenvolvidas focalizam risco na perspectiva da linguagem em uso. No referencial que estamos elaborando no Núcleo de Pesquisa em Psicologia Social e Saúde da Pontifícia Universidade Católica de São Paulo (Spink \& Frezza, 1999; Spink \& Medrado, 1999; Spink \& Menegon, 1999), várias dimensões de uso da linguagem são enfatizadas. Buscamos, de um lado, entender a construção de conceitos no âmbito de domínios de saber específicos e sua cristalização em discursos. Falamos, nesse caso, de discursos ou do uso institucionalizado de repertórios interpretativos. Mas buscamos também entender a linguagem na perspectiva dinâmica de uso no contexto das práticas discursivas. Focalizamos, nessa perspectiva, os processos de interanimação dialógica que pontuam as trocas lingüísticas e a dinâmica de posicionamentos que daí emergem.

Entretanto, seja no enfoque dos discursos cristalizados, seja no das práticas discursivas, é a noção de repertório interpretativo (Potter \& Wetherell, 1987) que ocupa o papel teórico central. Chamamos de repertório interpretativo o conjunto de termos, conceitos, lugares-comuns e figuras de linguagem utilizados para fal ar de um fenômeno específico. Sendo produções culturais e estando inscritos nos textos, imagens e lugares de memória que constituem o imaginário social, os repertórios são melhor compreendidos quando abordados no tempo longo da história. A familiarização com essas produções implica, portanto, a realização de uma arqueologia dos usos dos repertórios em diferentes épocas históricas. Constituem, nessa perspectiva arqueológica, um reservatório de sentidos passíveis de serem reativados nos processos de compreensão do mundo, que chamamos de produção de sentidos.

Com o objetivo de entender os repertórios sobre risco do ponto de vista arqueológico dos contextos históricos de uso, foi feita uma extensa pesquisa bibliográfica sobre a emergência, circulação e uso da linguagem do risco em diferentes domíni os do saber. Tratava-se de um projeto ambicioso que abarcou a etimologia da palavra risco e seu emprego no contexto dos jogos, da economia, da saúde, da tecnologia e da biotecnologia, buscando entender as múlti- 
plas dimensões do debate sobre risco presentes em inúmeros textos publicados em livros e artigos. É com base nessa vasta revisão da literatura que forneceremos uma visão panorâmica dos sentidos históricos de risco.

Uma visão panorâmica dos sentidos históricos de risco: o enredo arquetípico dos discursos sobre o risco

Mesclam-se nesta panorâmica três dimensões: uma forma de se relacionar com o futuro, uma forma de conceituar risco e uma forma de gerir os riscos. Considerando, inicialmente, o risco como uma forma específica de se relacionar com o futuro, nunca é demais reiterar que a palavra risco emerge na pré-modernidade, ou seja, na transição entre a sociedade feudal e as novas formas de territorialidade que dariam origem aos Estados-nação. Obviamente, a humanidade sempre enfrentou perigos diversos, sejam os riscos involuntários decorrentes de catástrofes naturais - terremotos, erupções vulcânicas, furacões - sejam aqueles associados às guerras, às vicissitudes da vida cotidiana ou ainda os voluntários, decorrentes do que chamaríamos hoje de "estilo de vida". Entretanto, esses eventos não eram denominados riscos. Eram referidos como perigos, fatalidades, hazards ou dificuldades, mesmo porque a palavra risco não estava disponível nos léxicos das línguas indo-européias.

Assim, a própria emergência da palavra risco no catalão no século XIV, nas línguas latinas no século XVI e nas anglo-saxônicas no século XVII já constitui um rico campo de investigação. Embora tenhamos engrossado as fileiras dos etimólogos diletantes, não se trata aqui de explicitar as hipóteses prováveis desse surgimento tardio do vocábulo. Basta ressaltar o consenso de que a palavra emerge para falar da possibilidade de ocorrência de eventos vindouros, em um momento histórico onde o futuro passava a ser pensado como passível de controle.

Vale fazer aqui uma breve digressão sobre as diversas possibilidades de pensar o futuro. Pierre Bourdieu, em texto publicado originalmente em 1963, defende a tese de que as disposições sobre o futuro estão associadas às condições materiais de existência, que permitem ou não defini-lo como “...uma estrutura particular de probabilidades objetivas - um futuro objetivo" (Bourdieu, 1979:8). Apoiando-se em pesquisas etnográficas e estatísticas, realizadas na Argélia entre 1958 e 1961, considera que a adaptação à economia capital ista implica a incorporação da disposição à previsibili- dade e cálculo que, por sua vez, “... exige uma disposi ção determinada em relação ao tempo e, mais precisamente, em relação ao futuro, sendo que a 'racionalização' da conduta econômica supõe que toda existência se organiza em relação a um ponto de fuga ausentee imagi nário" (Bourdieu, 1979:18-19).

É esse tipo de relação com o futuro que gera o clima propício à incorporação plena da perspectiva do "risco". Não que haja uma ausência de qualquer disposição ante o futuro numa economia pré-capitalista. Trata-se, entretanto, de um futuro pautado na "previdência" - a habilidade de "ver de antemão" a partir da inscrição na própria situação, a partir da identidade entre tempo de trabalho e tempo de produção. Como afirma Bourdieu (1979:22), “Ionge de serem ditados pelo desejo prospectivo de um futuro proj etado, as condutas de previdência obedecem ao cuidado de se conformarem aos model os herdados". Já o capitalismo impõe que se rompa essa unidade. Opõe, assim, ao "futuro prático", lugar de potencialidades objetivas, a noção de futuro como lugar dos possíveis abstratos de um sujeito intercambiável.

Mais uma vez é preciso deixar claro que não se trata da ausência da possibilidade de cálculo. O que Bourdieu parece afirmar é que, nas economias pré-capitalistas, o cál culo está a serviço da eqüidade, pautada num espírito de solidariedade, mas “opõe-se em absoluto ao espírito do cálculo que, fundamentando-se na avaliação quantitativa do lucro, anula as aproximações arriscadas e desinteressadas (pelo menos nas aparências) de uma moral de generosi dadeehonra" (Bourdieu, 1979:35).

A transição de um futuro pautado em solidariedade para outro marcado pelo cálculo dos riscos, pode ser traçada a partir dos repertórios lingüísticos disponíveis para significar o futuro. Há, conforme discutimos em textos anteriores (Spink, 2001), uma incorporação gradativa de termos, passando de fatalidade à fortuna (Giddens, 1991), e incorporando paulatinamente os vocábulos hazard (século XII), perigo (século XIII), sorte e chance (século XV) e, no século $X \mathrm{VI}$, risco.

Após emergir como vocábulo na pré-modernidade, risco haveria de tornar-se um conceito fundamental na modernidade clássica. Entretanto, a possibilidade de efetivamente utilizar o conceito de risco como estratégia de governo, envolve um longo processo de formalização que pode ser melhor entendido como o enredo arquetípico do desenvolvimento da compreensão, segundo as teorizações de White (1994) sobre os trópicos do discurso. De acordo com esse autor, o enredo arquetípico das for- 
mações discursivas parece exigir que o discurso se mova de uma caracterização metafórica original de um domínio de experiência, passando pela desconstrução metonímica de seus elementos, pelas representações sinedóquicas das relações entre seus atributos e sua suposta essência, chegando então à elaboração dos contrastes e oposições que possam ser discernidos nas representações sinedóquicas, fase que denomina ironia.

No caso do conceito de risco, esse longo processo envolveu, de um lado, o lento desenvolvimento da teoria da probabilidade, cuja história, que tem início no século XVII , é pontuada de heróis da matemática, incluindo aí Pascal, Fermat, Leibniz e De Moivre. Essa história é contada de forma coloquial por Peter Bernstein (1997), no livro O Desafio aos Deuses, e na linguagem social da Filosofia por Ian Hacking (1975), no livro The Emergence of Probability.

De outro lado, o conceito de risco envolve a sofisticação da estatística e seu uso como ciência do estado. Nunca é demais apontar que a raiz de estatística é status, que em latim quer dizer estado ou condição. Em seu sentido inicial, a estatística era o ramo da ciência política que dizia respeito à coleção e classificação de fatos relevantes para a tarefa administrativa, e é nesse sentido que ela encontra uma primeira função no governo das populações na Ciência da Polícia dos estados alemães dos séculos XVIII e XIX (Pasquino, 1991).

Mas seria necessário o avanço do cálculo das probabilidades para que a mera coleção de dados se tornasse um instrumento fundamental de governo. É nesse contexto, então, que encontramos o primeiro deslocamento no enredo arquetípico do discurso sobre risco. Passamos da metáfora à metonímia e entramos na primeira fase da gestão dos riscos, que tem sua idade de ouro no século XIX, na ciência sanitária que será o berço do Estado do Bem-Estar Social.

Entretanto, será apenas em meados do século XX que passaremos à fase da sinédoque, com a progressiva formal ização do conceito e aperfeiçoamento das técnicas de cálculo dos riscos. Essa passagem, no domínio da epidemiologia, foi brilhantemente detalhada por José Ricardo Ayres (1997) em seu livro Sobre o Risco, eé ela que leva também, na segunda metade do século $X X$, à formatação de um campo de saber muito específico denominado gestão de riscos: um campo que resulta do casamento entre o cál culo de probabilidades e a herança da função política da estatística, e que irá gerar os sofisticados modelos de análise de riscos.

O campo interdisciplinar da análise dos riscos se inaugura, segundo alguns autores (entre eles: Hood et al., 1992; Renn, 1998), na década de 50 , no contexto dos riscos associados à energia nuclear. Esse campo desde cedo englobou três áreas de especialidade: o cálculo dos riscos (risk assessment), a percepção dos riscos pelo público e a gestão dos riscos. Mais recentemente, a gestão dos riscos passou a englobar também a comunicação sobre riscos ao público.

O cálculo dos riscos consiste na identificação dos efeitos adversos potenciais do fenômeno em análise, a estimativa de sua probabilidade e da magnitude de seus efeitos. Depende portanto, de quantificação, expressa na abordagem hegemônica do Quantitative Risk Assessment (Hood et al., 1992). A percepção dos riscos volta-se à relação entre o público e os riscos tecnológicos, estando associada portanto, ao estudo da aceitação de determinadas tecnologias, como vem acontecendo com as diversas aplicações modernas da engenharia genética. Volta-se também à perspectiva do controle preventivo dos riscos, buscando, por meio da educação, influir nos comportamentos deletérios para a saúde do corpo e do meio ambiente. A gestão dos riscos compreende quatro estratégias integradas: os seguros, as leis de responsabilização por danos, a intervenção governamental direta e a auto-regulação. Progressivamente, passou a incorporar também a comunicação sobre riscos, na medida em que a participação pública, quer na aceitação quer no autocontrole, passou a ser elemento imprescindível do controle social dos riscos.

Todas essas arenas iniciaram-se num clima de franco otimismo, mas progressivamente, depararam-se com críticas, sobretudo por parte de antropólogos vinculados à Mary Douglas e Aaron Wildavsky (Douglas, 1992; Douglas \& Wildavsky, 1983). A eles juntaram-se, mais tarde, sociólogos, ecologistas e pensadores oriundos de outros campos disciplinares, incluindo aí a Psicologia Social (por exemplo: Kadvany, 1997; Johnson \& Covello, 1987). O debate atual é rico e complexo demais para ser abordado neste texto, sendo importante apenas, para a argumentação aqui desenvolvida, apontar que duas dimensões estão aí imbricadas. Uma refere-se ao não-reconhecimento, nas abordagens iniciais, da questão dos valores que permeia não apenas a percepção do público, mas a própria definição do que vem a ser risco. A outra dimensão refere-se à transformação que vem ocorrendo na natureza dos riscos, progressivamente mais sistêmicos e globalizados. Nessa dimensão, o debate é técnico e questiona a própria possibilidade de cálculo de riscos cada vez mais imponderáveis.

Chegamos assim à quarta etapa do enredo arquetípico do discurso sobre o risco: a ironia. 
A gestão dos riscos é um fenômeno da modernidade tardia e, sendo uma forma de governar populações, devemos entender esse enredo na perspectiva das mudanças que vêm ocorrendo na esfera da governamentalidade e que levam muitos autores (entre el es Castel, 1991) a afirmarem que estamos vivenciando o fim da sociedade disciplinar (ou modernidade clássica) e o início da sociedade de risco (ou modernidade tardia). Isso implica entender como passamos do foco na gestão da vida para o foco na gestão do risco.

Da sociedade disciplinar à sociedade de risco: a gestão dos riscos na modernidade tardia

Para Foucault (1977), o que estava em pauta na sociedade disciplinar era a gestão da vida que, segundo as reflexões delineadas no livro A Vontade de Saber, englobou duas estratégias. Uma, desenvolvida a partir do século XVII, centrouse no corpo-máquina constituindo os di spositivos disciplinares. A outra, um pouco mais tardia, desenvolvendo-se por volta de meados do século XVIII, centrou-se no corpo-espécie e englobou as técnicas de governo das populações. É no âmbito dessas últimas que se constituirão os biopoderes essenciais para a moderna gestão dos riscos.

O poder disciplinar, fundamental para o desenvolvimento do capitalismo industrial, tinha por objetivo o controle dos corpos, tornando-os dóceis e fortalecidos para o trabalho produtivo. Ancorava-se duplamente na organização da massa indiferenciada mediante sistemas classificatórios e nas estratégias de vigilância continuada. O principal mecanismo classificatório nesse tipo de gestão era a norma, e mais precisamente a definida a partir das distribuições de freqüência. Dessa forma, essa organização era perpassada pela noção do “homem médio", introduzida por Lambert Adolphe Jacques Quetelet e aperfeiçoada por Francis Galton (Bernstein, 1997).

Também a vigilância dependia de dois mecanismos. De um Iado, apoiava-se nas "disciplinas", saberes específicos constituídos e constituidores das instituições de vigilância: a escola, a prisão, por exemplo. De outro lado, para que essas ordenações fossem internalizadas, a vigilância dependia de um regime disciplinar exercido no espaço privado dos lares e das subjetividades: a higiene.

Já os biopoderes voltam-se ao governo do corpo-espécie e têm por objetivo a segurança, estratégia de governo que implica o aperfeiçoa- mento e uso da informação. É importante, nessa perspectiva, entender os riscos e seus correlatos. É importante também que se desenvolvam instituições especializadas na análise dessas séries quantitativas. É obviamente nessa vertente que se ancoram as modernas estratégias de gestão dos riscos.

Entretanto, Foucault pensa a modernidade clássica. Seu projeto, segundo explicitação no texto Politics and the Study of Discourse, de 1968, buscava determinar, em suas diversas dimensões, como deve ter sido o modo de existência dos discursos e particularmente dos discursos científicos (suas regras de formação, com suas condições, dependências e transformações) na Europa, desde o século XVII, de maneira que o conhecimento que é nosso hoje, pudesse ter vindo a existir, mais particularmente, aquele que tomou como seu domínio o curioso objeto chamado homem (Foucault, 1991).

No entanto, para entender os deslocamentos ocorridos mais recentemente, a referência fundamental é UIrich Beck (1993). Para Beck, o projeto da modernidade tardia implica a gestão dos riscos (e não mais a gestão da vida). Beck introduz o conceito de soci edade de risco para referir-se a esses deslocamentos, que incluem três características: a globalização, a individualização e a reflexi vidade.

A gl obalização, na visão de Beck, se refere à interseção de ausência e presença ou ao entrelaçamento de relações e eventos sociais que estão distantes dos contextos locais. Trata-se do processo de separação das relações entre tempo e espaço que tem como conseqüências a desterritorialização. Essa articulação de relações sociais que atravessam vastas fronteiras de tempo e espaço torna-se possível porque o movimento - de pessoas, de produtos e de informação - passou a ser facilitado pelos avanços nos meios de transporte. Entretanto, não é essa a marca registrada da globalização; sua condição si ne qua non são os desenvolvimentos na mídia eletrônica.

Quanto à individualização, não se trata mais da identificação do singular na massa, fato que decorre dos processos classificatórios da sociedade disciplinar, mas da singularização por meio da destradicionalização. Beck se refere, com esse termo, às transformações que vêm ocorrendo nas instituições tradicionais família, trabal ho e educação - que fazem com que as biografias tornem-se projetos reflexivos e, como tal, processos centrais na constituição da subjetividade contemporânea.

Por sua vez, a reflexividade refere-se à suscetibilidade à revisão crônica da maior parte dos aspectos da atividade social e das relações 
com a natureza, à luz de novas informações, processo esse que perpassa nossa vida cotidiana, pensada como esfera privada, o projeto da ciência e a própria atividade de governo. Tratase, assim, de mais um indicador da presença da ironia em nossas formações discursivas, entendendo-a (como sugere White) como capacidade não só de dizer coisas sobre o mundo de maneira particular, mas também de dizê-las de maneira alternativa.

Não que as estratégias de governo anteriores - a soberania e a disciplina - não continuem a vingar. Foucault bem nos adverte. Mas há deslocamentos importantes que fazem com que as novas modalidades de biopoderes se tornem as principais estratégias de gestão. O que muda? Diríamos que muda a natureza dos riscos, os mecanismos de gestão das populações e as estratégias de gestão no nível das pessoas.

Quanto à natureza dos riscos, Beck e outros sociólogos (entre eles Giddens, 1998) falam de sociedade de risco para pontuar a complexidade dos riscos modernos, complexidade essa que se refere à natureza dos riscos - enfatizando a presença crescente dos riscos manufaturados, produtos dos desenvolvimentos da ciência e tecnologia - e à progressiva tendência à desterritorialização e globalização desses riscos. Emerge daí uma nova sensibilidade: a percepção crescente de que os riscos são sistêmicos, acompanhada da consciência da imponderabilidade dos riscos e da necessidade de mecanismos igualmente complexos de gestão do imponderável.

Essas novas formas de gestão no nível das populações trazem em seu bojo quatro aspectos interessantes. Inicialmente, a emergência de sistemas de gestão que são transdisciplinares, transdepartamentais e transnacionais. Em segundo lugar, a necessidade de mecanismos sofisticados de gestão de informação que atravessem domínios de saber: redes interligadas de informação, conforme descrito por Richard Ericson \& Kevin Haggerty no livro Policing the Risk Soci ety (1997). I mpõem também, a necessidade de ressignificação da ética, que passa a ser não mais uma ética prescritiva, mas dialógica com o imperativo da consulta a representantes da sociedade civil (Spink, 2000a). Finalmente, implica a emergência de novas modalidades de movimentos de resistência que utilizam as facilidades de acesso à Internet, traduzindo-se em movimentos sociais globalizados.

Já a gestão no nível da pessoa, concerne sobretudo ao imperativo de gestão da informação numa sociedade cada vez mais destradicionalizada e à luz de mudanças substantivas na natureza da informação, e até mesmo nos mecanismos de circulação da informação. Assim, a informação na sociedade globalizada prescinde das instituições educativas (ou as transforma); passa a ser um processo contínuo que se dá dentro e fora dos espaços institucionais da educação. Sendo caracteristicamente capilar, se difunde por meio das várias tecnologias de informação (e não mais apenas por meio de livros). Tornando-se uma exigência para a produção de sentidos no cotidiano, implica novas formas de vigilância, agora subsumidas pelo autocontrole do estilo de vida e pela monitoração constante de indicadores de qualidade, como no caso prototípico dos diagnósticos preventivos em saúde.

O cruzamento do imperativo da informação com os processos de destradicionalização tem implicações importantes. Há, antes de tudo, uma tendência à desnormalização, sendo a norma substituída pelo imperativo da opção. Mas há também, a emergência de anteparos variados à destradicionalização, entre eles a busca do sentido da vida na emoção e adrenalina. Isso nos leva ao último tópico da contextualização imprescindível para o argumento aqui desenvolvido: a função do risco-aventura nesse cenário de gestão dos riscos.

\section{A destradicionalização do risco: o risco-aventura como metáfora da modernidade tardia}

Temos defendido em outros textos sobre risco (Spink, 2001) a existência de uma dimensão positiva no enfrentamento dos riscos. Há uma velha conexão entre risco e aventura, valorizada pela ousadia passível de levar a descobertas. Por exemplo, a companhia de seguros Winterthur International, membro do Credit Suisse Group - que se auto-definem como "the experts in total risk management" -, produziu uma bela série de anúncios enfatizando a ousadia do risco. Trata-se de fotos dramáticas em branco e preto, com fundo preto, de autoria de Richard Avedon, com celebridades do calibre de Maurice Béjart (coreógrafo), Giovanni Agnelli (empresário) e Lord Attenborough (cineasta), que falam de seus mundos na linguagem do risco. Por exemplo, no anúncio publicado na revista The Economist em 1998 (Winthertur International, 1998:56-57) Maurice Béjart afirma: “Dançar à beira deum vulcão éa mais bela metáfora que conheço para risco. E ter a coragem decorrer riscos éa maior motivação para toda a dança".

Há também uma velha conexão entre risco eformação decaráter, expressa no valor educativo da aventura. Um dos mais antigos empre- 
endimentos comerciais de educação através da aventura é o Outward Bound, com início em 1941, no País de Gales, Grã-Bretanha, resultado de uma parceria entre Kurt Hahn, educador, e Lawrence Holt, sócio de uma empresa de transporte marítimo. O objetivo original era treinar por meio do corpo, em oposição a treinar o corpo (Martin, 1994). Esse projeto teve imenso sucesso no pós-guerra, estando hoje firmemente implantado em diversos países. Sua página na Internet বhttp:// www.outwardbound.org>descreve os cinco valores que norteiam esse tipo de educação: (a) aventura e desafio, (b) compaixão e serviço, (c) aprendizagem por intermédio da experiência, (d) desenvolvimento pessoal, (e) responsabilidade social e ambiental. Seu projeto educativo é descrito da seguinte maneira: “Até mesmo num ambiente tão pouco domesticado como a natureza (wilderness) há método em nossa loucura. Todos os componentes de um curso outward bound o ajudam primeiramentea conhecer-se mel hor, depois o ensinam a abrir-se (reach out) eajudar aos outros em sua equipe. É essa combinação queo ajuda a ver as coi sas com novos ol hos efaz do outward bound uma experiência incrível".

Há, finalmente, uma velha conexão entre risco e aposta, em sua essência de potencialidade de ganhos e perdas, que deixou marcas profundas no domínio da economia. A revista Exame, de 13 de agosto de 1997, trazia como tema de capa a reportagem intitulada Os Homens do Risco, com a seguinte chamada: “Bemvindo ao mundo de intensa adrenalina da Linear. Emoção éo que não falta a quem se aventura por seus fundos de al to risco - que podem fazer a felicidade (ou a depressão) do investidor" (Figura 1). A reportagem argumentava a favor da tese de que sem perigo não se avança no projeto da modernidade. Parafraseando Bernstein (1997), o autor da matéria afirma: "Sem o domínio da teoria das probabilidadese de outros instrumentos de administração de risco, os engenhei ros jamais teriam projetado as grandes pontes, os lares ainda seriam aquecidos por lareiras e as viagens espaciais ainda seriam um sonho. (...) A capacidade de administrar o risco ea vontade de correr riscos e de fazer opções ousadas são el ementos- chave da energia que impulsiona o sistema econômico" (Fucs, 1997:99).

É oportuno lembrar que, em seus primórdios, o desenvolvimento da teoria da probabilidade apoiou-se duplamente no cenário dos jogos de aposta e na astronomia. Por exemplo, há um famoso problema matemático concernente à distribuição do valor das apostas em um jogo interrompido, que circulou na Europa
Figura 1

O risco como motor da economia.

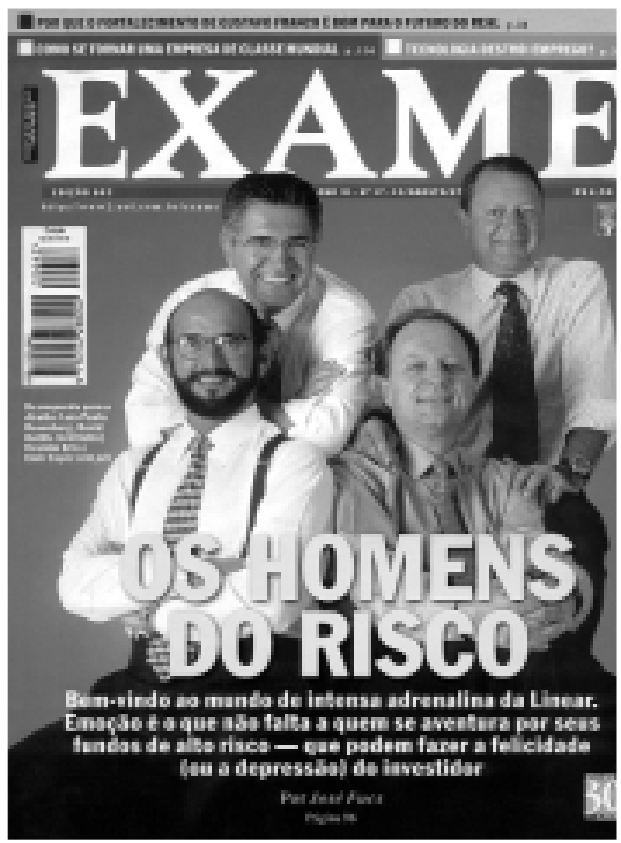

durante quatro séculos. Introduzido por Fibonacci no século XIII, foi finalmente resolvido por Pascal e Fermat no século XVII, por meio do cálculo da probabilidade da seqüência de ganhos e perdas no desenrolar do jogo.

Essa modalidade de enfrentamento de riscos é fortemente marcada pela aventura, definida aqui apenas como a disposição de correr riscos. Trata-se de um componente importante da modernidade, expressa, por exemplo, na disposição de investir, motor principal da economia liberal. Há, aliás, um fértil campo de pesquisa voltado ao estudo do comportamento do homo economicus, que busca entender a tomada de decisão em situações de risco. Basta citar como exemplo duas vertentes de pesquisa hoje clássicas: a teoria de jogos de John Von Neumann \& Oscar Morgenstern (1947) e a teoria de decisão dos psicólogos cognitivos associada ao trabalho de Amos Tversky e Daniel Kahneman (Kahneman \&Tversky, 1984; Tversky \& Kahneman, 1981).

Entretanto, deparamos hoje com novas modalidades de aventura, seja na vertente dos esportes radicais, seja na busca da emoção exacerbada pelas drogas lícitas e ilícitas. Alguns autores (entre eles Giddens, 1991; Le Breton, 1996) vêm procurando entendê-las à luz das características da sociedade de risco, situando- 
as como formas de anteparo aos processos de destradicionalização que acompanham a globalização. Temos assumido a posição de que, para entendê-las, é preciso antes de tudo situálas no contexto dos jogos. Optamos, para isso, pelas teorizações hoje clássicas de Roger Caillois (1958).

Caillois baseia seu modelo de jogos (Tabela 1) na interseção de duas dimensões: as diferentes modalidades de jogos e o grau de disciplinarização dos jogos. Propõe, dessa forma, quatro modalidades básicas de jogos: agôn, jogos de competição; alea, jogos de chance; mimicry, jogos de simulacro e ilinx, jogos de vertigem. As quatro modalidades aparecem em duas formas: uma mais espontânea (ou primitiva) - a pai di a e a outra mais regrada - o ludus. Podemos pensá-las na perspectiva da sociogênese, ou seja, a paidia como uma forma menos socializada dos jogos, típica, por exemplo, da infância e o ludus como a forma disciplinada, socializada e presa a regras de comportamento.

Um dos fenômenos mais surpreendentes da época atual é o crescimento vertiginoso, quase desenfreado, dos jogos de vertigem (ilinx) e é nesse contexto que situamos o risco-aventura. Faz parte desse movimento de expansão, a emergência das diversas novas formas de esportes de aventura, tendo como precursora a Whitbread Ocean Race, com início em 1973. Herdeira das disputas informais entre os tea clippers que faziam a rota entre Europa e Ásia no século passado, a Whitbread mobiliza hoje alta tecnologia e recursos sofisticados, sem deixar de apelar para a emoção dos riscos inerentes ao enfrentamento dos oceanos.

A década de setenta introduz modalidades de risco-aventura que utilizam veículos motorizados, especialmente as disputas de veícu- los off-the-road, sendo as mais conhecidas o Rali Paris-Dakar, iniciado em 1979, e o Camel Trophy, realizado em lugares inóspitos em diferentes países a partir de 1980.

O final dos anos 80 vê emergir novas modalidades de risco-aventura: os ralis humanos. A primeira competição nessa nova modalidade teria sido o Raid Gauloise, concebido por um jornalista francês, Gérard Fusil e realizado pela primeira vez na Nova Zelândia em 1989. Já o Eco-Challenge Lifestyles Inc., fundado por Mark Burnett em 1992, como sugere o nome, inova por associar aventura com ecologia. Trata-se, como seu antecessor, de uma competição de resistência que envolve múltiplas modalidades de esporte: montaria a cavalo, canoagem, escalada, rapel, mountain bike e longas caminhadas. Tem como ingredientes principais o trabaIho em equipe, a resistência, o espírito de aventura e a compaixão, mesclados com a consciência ecológica manifesta não só no respeito absoluto à natureza ("pack it in, pack it out, no camp fires, camp and travel only where permitted" é o lema dos aventureiros ecologistas), como também na ação ambiental efetiva apoiando iniciativas locais. Também nós, no Brasil, aderimos aos ralis humanos, inicialmente com a Expedição Mata Atlântica, organizada pela Soci edade Brasileira Multisport Adventure Racing a partir de 1998, e mais recentemente com os programas populares de sobrevivência, como o recente No Limite.

Entretanto, o ilinx não se manifesta apenas nessas formas disciplinadas de jogos de vertigem características do ludus. Para entender a multiplicidade de modalidades de risco-aventura é conveniente recorrer mais uma vez a Caillois e a sua proposta de que o ludus pode ter formas culturais e institucionais, assim co-

Tabela 1

A classificação dos jogos segundo Roger Caillois.

\begin{tabular}{|c|c|c|c|c|}
\hline & Agôn (competição) & Alea (chance) & Mimicry (simulacro) & Ilinx (vertigem) \\
\hline $\begin{array}{l}\text { Paidia (algazarra, } \\
\text { alarido, tumulto, } \\
\text { agitação, riso solto) }\end{array}$ & $\begin{array}{l}\text { Corridas } \\
\text { Lutas }\end{array}$ & $\begin{array}{l}\text { Tesoura, pedra, papel } \\
\text { Cara ou coroa }\end{array}$ & $\begin{array}{l}\text { Jogos de ilusão } \\
\text { Máscaras } \\
\text { Fantasias }\end{array}$ & $\begin{array}{l}\text { Carrossel } \\
\text { Dança }\end{array}$ \\
\hline $\begin{array}{l}\text { Ludus (esportes } \\
\text { com regras, técnicas } \\
\text { e equipamentos) }\end{array}$ & $\begin{array}{l}\text { Boxe } \\
\text { Esgrima } \\
\text { Futebol } \\
\text { Bilhar } \\
\text { Damas } \\
\text { Xadrez }\end{array}$ & $\begin{array}{l}\text { Apostas } \\
\text { Roleta } \\
\text { Loterias }\end{array}$ & $\begin{array}{l}\text { Teatro } \\
\text { Circo }\end{array}$ & $\begin{array}{l}\text { Esqui } \\
\text { Alpinismo } \\
\text { Bungee jump }\end{array}$ \\
\hline
\end{tabular}

Fonte: Roger Caillois (1958). 
mo formas corrompidas. As formas culturais englobam todas as modalidades de esportes que exaltam a velocidade, a adrenalina, a obliteração da razão pela concentração total na ação. Por exemplo, o esqui, o al pinismo, o surfe e as diversas modalidades de esportes que envolvem desafio, sobrevivência e vertigem.

As formas institucionais se fazem presentes sobretudo nas profissões que exigem o domínio da vertigem. Inserem-se aqui as tradicionais profissões de risco, como os guias de montanha, os bombeiros, os detetives. Mas inserem-se também as novas profissões que emergem em conseqüência dos riscos manufaturados. Ericson \& Haggerty (1997:102) definem as novas profissões do risco como "um grupo ocupacional que reivindica para si um conhecimento abstrato e exclusivo sobre como lidar com riscos específicos, assim como a habilidade de prover serviços especializados para gerenciar esses riscos". Incluem-se aqui os gerentes de risco em bancos de investimento, os responsáveis pela segurança de tecnologias capazes de induzir a desastres em larga escala, como a energia nuclear e os responsáveis pela segurança das novas tecnologias associadas à engenharia genética.

Caillois propõe ainda que há formas corrompi das dos jogos de vertigem em que a razão é obliterada, por exemplo, pelo uso de drogas psicotrópicas, sejam elas lícitas ou ilícitas. Essa é a forma de risco que David Le Breton (1996) chama de blancheur. Trata-se do inverso da vertigem e do desafio - em que o risco é ativamente buscado - com a atração direcionada para o menos e não para o mais: longe de provocar a morte, há um doce abandono a ela por meio do álcool, da droga, da fuga ou da vagabundagem.

São essas dimensões do risco que vêm sendo foco de reflexão de tantos autores. Alguns buscam entender a onipresença das formas culturais do risco-aventura, subsumidas pelos esportes-radicais, como forma de expansão dos processos de disciplinarização para além de suas formas institucionais. A aventura, nessa interpretação, passa a ser incorporada ao cotidiano como estratégia de edificação. Encontramos na mídia exemplos variados dessa função edificadora do risco-aventura, entre eles:

a) O fortalecimento do caráter, como na reportagem de capa da Veja São Paulo, de março de 1998 (França, 1998), intitulada Uma Turma Movida a Adrenalina: Os Riscos, os Benefícios, as Emoções e os Desafios dos Esportes Radicais Praticados por Aventurei ros Infantis (Figura 2).

b) A aprendizagem de flexibilidade e decisão nos programas de treinamento e desenvol-
Figura 2

Crianças radicais - o risco como fortalecimento do caráter.

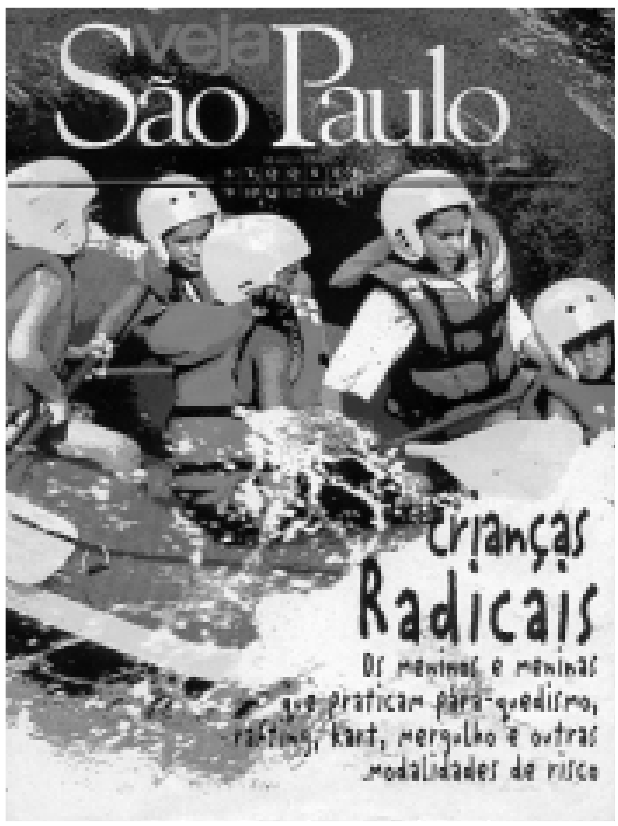

vimento gerencial, como o Quest, desenhados para dar à gerência corporativa um recurso de treinamento al ternativo que combina a emoção da aventura outdoor com o treinamento corporativo tradicional. Segundo descrição fornecida no site, "o conceito éaprender fazendo fazendo algo fora do escritório que apresenta desafios que podem então ser transferidos para o mundo real do trabal ho" (Quest: «ttp:// www.lagunaphuket.com/ quest/ corporate_ training.htm $>$ ).

c) Ou ainda, a busca de novos espaços para o fortalecimento dos laços familiares, como apregoa a reportagem de capa da Veja São PauIo, de junho de 1999 (França, 1999), intitulada Laços de Adrenalina: Pais e Fil hos Descobrem na Natureza, em Surpreendentes Aventuras de Fim de Semana, a Chave para uma Convivência mais Estreita.

Outros autores focalizam as formas corrompidas e buscam entendê-las na perspectiva dos processos de destradicionalização, próprios da sociedade globalizada e do capitalismo informacional. Insere-se nessa vertente a instigante reflexão de David Le Breton (1996), que analisa tanto as formas culturais quanto as formas corrompidas dos ilinx modernos na perspectiva do ordálio, ou seja: a busca de significado para a vida no enfrentamento da morte, dando chan- 
ces iguais de dela escapar. Em suma, "quando o sentido da vida escapa, quando tudo éindiferente, o ordálio é uma solução. É a única estrutura antropológica que pode dar uma segunda chance. Ela metaforiza a morte por meio de uma troca si mbólica em que o ator aceita que, para poder tudo ganhar, arrisca tudo perder" (Le Breton, 1996:58).

São caminhos possíveis, mas que não esgotam as explicações sobre a onipresença do risco-aventura na sociedade contemporânea. $\mathrm{O}$ que estamos propondo, entretanto, é que busquemos fugir da sedução dos esportes-aventura ou do questionamento das formas corrompidas de ilinx, focalizando o risco-aventura a partir de um novo olhar, buscando entender os usos metafóricos a que se prestam para falar não mais de riscos mas de imponderabilidade.

\section{O uso metafórico do risco-aventura}

Desde que nos embrenhamos na pesquisa sobre risco, temos colecionado matérias sobre o assunto em jornais e revistas, nacionais e estrangeiras, incluindo anúncios e propagandas que utilizam a linguagem do risco. Analisando as matérias que traziam a palavra risco no seu título, publicadas na Fol ha deSão Paulo no período de 1921 a 1998 (Spink, 2000b), verificamos um uso crescente em todas as áreas de reportagem, incluindo esporte, economia, saúde e política. Muitas dessas matérias focalizavam o "risco em si", seja como metonímia, seja como sinédoque. Mas outras faziam um uso metafórico do termo, que era utilizado para falar de algo que, embora relacionado, já não era mais risco.

Esse deslocamento fica mais claro quando analisamos as imagens; em suma, muito recentemente começamos a encontrar imagens relacionadas a risco-aventura que já não remetem mais à palavra risco. É possível ilustrar esse deslocamento contrastando dois usos de risco em imagens. O primeiro é um anúncio de uma empresa de seguros, a Allianz Group, que se descreve como "líder em seguros e serviços financei ros na Europa", publicado na Veja, em maio de 2000. A belíssima imagem, aqui apresentada na forma de croquis dada a recusa de autorização para sua reprodução, mostra um operário sentado em uma viga de prédio em construção, "no topo do mundo" com a cidade aos seus pés.

A mensagem é clara: onde quer que você esteja, a Allianz dará cobertura: “para nós, administração de riscos significa pensar o impensável para evitar que riscos se transformem em perdas. Como uma das maiores seguradoras do mundo, temos a solidez financeira ea capacidadetécnica que fazem da Allianz uma parceira em que vocêpode confiar quando eonde pre cisar" (Allianz Group, 2000:100-101). O anúncio fala tanto da necessidade como da positividade do risco, mas a partir da segurança decorrente da escolha de bons gerentes de risco. Embora se apóie na metáfora para a comunicação da mensagem, a associação entre a necessidade de correr riscos e os resultados potencialmente positivos da empreitada é feita no contexto do gerenciamento racional dos riscos ( $\mathrm{Fi}$ gura 3).

Já a segunda imagem nem mesmo fala em riscos, embora eles estejam presentes quer na foto quer na idéia de volatilidade dos fundos. Trata-se de um de três textos publicados na revista inglesa TheWeek, de 29 de abril de 2000, na seção intitulada Making Money: What the Experts Think. O texto em questão, intitulado Thrill Seekers or Sound Sleepers (os que buscam emoções ou os que preferem um sono tranqüilo), discutia a opção por fundos voláteis. Iniciava afirmando que "a maioria dos investidores evita a volatilidade excessiva, mas para o jogador hiperativo que gosta de entrar e sair de uma ação em poucas horas, as altas e baixas oferecem possibilidades maiores delucro a curto-prazo" (Week, 2000:35). Concluía, assim, que as ações menos voláteis são mais adequadas para investidores que preferem "dormir à noite".

O texto vem acompanhado da Figura 4, também apresentada na forma de croqui, que

Figura 3

O risco com segurança.

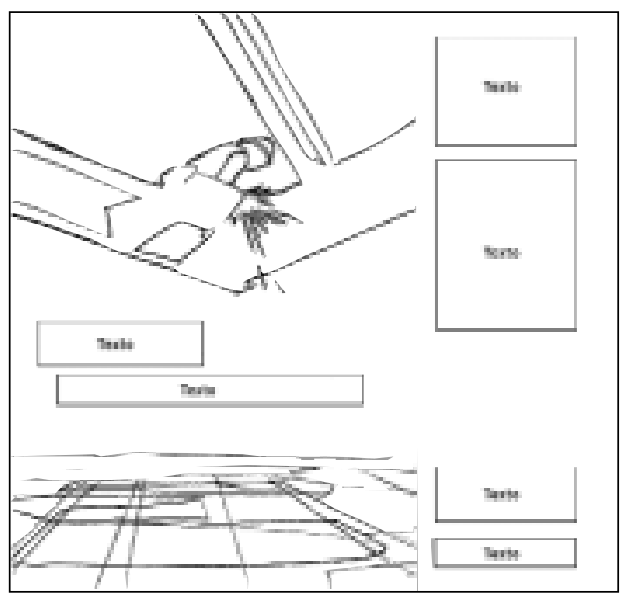


tem por subtítulo Volatilidade: Apenas para os queBuscam Emoções. O salto no espaço, provavelmente na modalidade de bungeejump, fala metaforicamente de risco como aventura, sendo esta uma atividade própria de quem busca emoções e, como na reportagem sobre os homens do risco apresentada anteriormente, tem "coração forte".

\section{Considerações finais}

Concluindo, é esse deslocamento, do risco metonímico para o metaforizado, que deveria ser o foco de nossas análises, por ser indicativo da emergência de novos discursos sobre risco. Nestes, não é mais o risco, mas a imprevisibilidade, a imponderabilidade e a complexidade que marcam nossas experiências cotidianas; são indicativos, portanto, do deslocamento da sociedade disciplinar para a de risco a que nos referimos anteriormente.

Buscando fazer uma síntese das muitas tramas abordadas neste texto, concluiríamos reiterando quatro aspectos. Em primeiro lugar, risco emerge como conceito quando se torna possível pensar o futuro como passível de controle. Esse é um processo que envolve tanto o desenvolvimento do instrumental necessário (como a teoria da probabilidade) quanto a emergência de um novo objeto de governo (a população).

Em segundo lugar, da pré-modernidade à modernidade clássica, a gestão dos riscos se formata em duas vertentes distintas: a prevenção e a aposta. Ambas são frutos da crença na racionalidade, mas geram mecanismos de controle distintos. Na vertente da prevenção, o principal mecanismo de controle é a norma, definida por meio da média estatística. Já na vertente da aposta, elemento essencial do comportamento em uma economia liberal, o principal mecanismo de gestão é a tomada de decisão informada que privilegia o processamento da informação numa perspectiva cognitiva intra-individual.

Em terceiro lugar, na transição para a sociedade de risco ocorrem várias transformações: a crença na possibilidade de controlar o futuro a partir da agregação e análise de séries de informações, passa a ser questionada frente à natureza sistêmica dos riscos manufaturados; a norma cede lugar à probabilidade como mecanismo de gestão e a gestão dos riscos no espaço privado se desprende dos mecanismos tradicionais de vigilância, pautados nas instituições disciplinares, e passa a depender do gerenciamento de informações que são de todos
Figura 4

Risco, volatilidade e imponderabilidade.

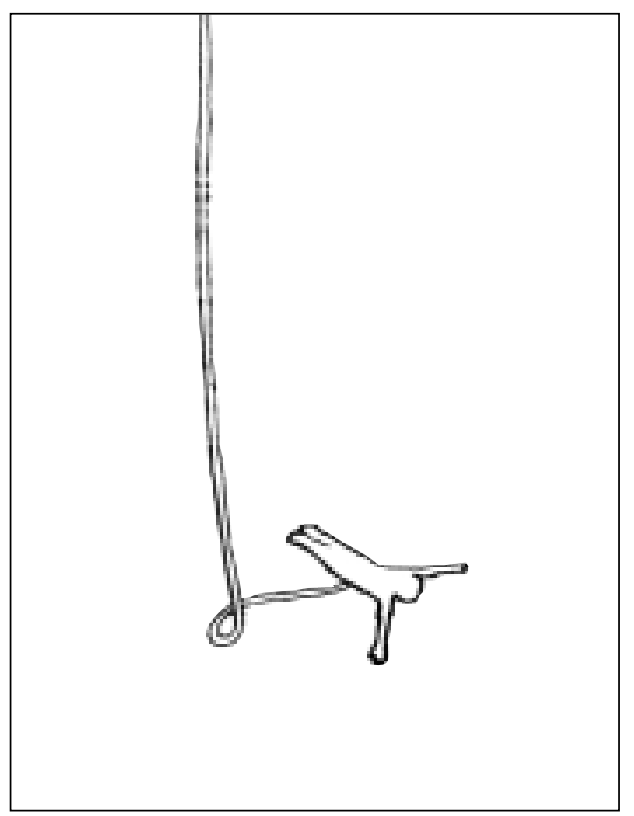

e não são de ninguém. Amplia-se assim, a experiência intersubjetiva do imperativo da opção, gerando novos mecanismos de exclusão social.

Finalmente, é possível que ainda não tenhamos os conceitos necessários para expressar essas novas sensibilidades, gerando assim um solo fértil para a emergência de novos termos, utilizados ainda em sentido figurativo.

Retomando a teoria tropológica de White (1994), é possível propor que o tempo longo da gestão dos riscos nos leva do uso metafórico, como aposta no cenário dos jogos, para o metonímico, em que impera a norma associada à média estatística, à fase da sinédoque, na qual se formaliza o conceito probabilístico de risco, até a fase da ironia, entendida como o questionamento a partir da contraposição de explicações alternativas. Se a interpretação dessa trajetória do conceito de risco fizer sentido, então o estudo minucioso das novas formas de falar sobre ele e as funções que essas práticas discursivas têm na vida social, podem nos dar pistas sobre a emergência de novas formas de gestão na modernidade tardia e das possibilidades de produção de sentido a elas associadas. 
Referências

ALLIANZ GROUP, 2000. Anúncio. Veja, 3 mai:100-101. AYRES, J. R. C. M., 1997. Sobre o Risco: Para Compreender a Epidemiologia. São Paulo: Editora Hucitec.

BECK, U., 1993. Risk Society: Towards a New Modernity. Cambridge: Polity Press.

BERNSTEIN, P., 1997. O Desfio aos Deuses: A FascinanteHistória do Risco. Rio de Janeiro: Campus.

BOURDIEU, P., 1979. O Desencantamento do Mundo. São Paulo: Perspectiva.

CAILLOIS, R., 1958. LesJeux et les Hommes. Paris: Gallimard.

CASTEL, R., 1991. From dangerousness to risk. In: The Foucault Effect: Studies in Governmentality (G. Burchell, C. Gordon \& P. Miller, ed.), pp. 281-298, Chicago: University of Chicago Press.

DOU GLAS, M., 1992. Risk and Blame: Essays in Cultural Theory. London: Routledge.

DOUGLAS, M. \&WILDAVSKY, A., 1983. Risk and Culture Berkeley/Los Angeles: University of California Press.

ERICSON, R. \& HAGGERTY, K., 1997. Policing the Risk Society. New York: Oxford University Press.

FOU CAULT, M., 1991. Politics and the study of discourse. In: The Foucault Effect: Studies in Governmentality (G. Burchell, C. Gordon \& P. Miller, ed.), pp. 53-72, Chicago: University of Chicago Press.

FOU CAULT, M., 1977. A Vontade de Saber. Rio de Janeiro: Graal.

FRANÇA, V., 1998. Uma turma movida a adrenalina: Os riscos, os benefícios, as emoções e os desafios dos esportes radicais praticados por aventureiros infantis. Veja São Paulo, 11 mar:12-18.

FRANÇA, V., 1999. Laços de adrenalina: Pais e filhos descobrem na natureza, em surpreendentes aventuras de fim de semana, a chave para uma convivência mais estreita. Veja São Paulo, 2 jun:16-21.

FUCS, J., 1997. Os jogadores. Exame, 642:96-103.

GIDDENS, A., 1991. Modernity and Self-Identity. Cambridge: Polity Press.

GIDDENS, A., 1998. Risk society: The context of British politics. In: The Politics of Risk Society (J. Franklin, ed.), pp. 23-34, Cambridge: Polity Press.

JOHNSON, B. B. \& COVELLO, V. T. (ed.), 1987. The Social and Cultural Construction of Risk: Essays on Risk Selection and Perception. Dordrecht: Reidel.

HACKING, I., 1975. The Emergence of Probability: A Philosophical Study of Early Ideas About Probability, Induction and Statistical Inference. Cambridge: Cambridge University Press.

HOOD, C. C.; JONES, D.; PIDGEON, N.; TURNER, B. \& GIBSON, R., 1992. Risk management. In: Risk: Analysis, Perception and Management (The Royal Society, ed.), London: The Royal Society.

KADVANY, J., 1997. Varieties of risk representations. Journal of Social Philosophy, 28:123-143.

KAHNEM AN, D. \&TVERSKY, A., 1984. Choices, values and frames. American Psychologist, 39:341-350.

LE BRETON, D., 1996. Passions du Risque. Paris: Métailié.

MACHLIS, G. E. \& ROSA, E. A., 1990. Desired risk: Broadening the social amplification risk framework. Risk Analysis, 10:161-168.

MARTIN, E., 1994. FlexibleBodies. Boston: Beacon Press. PASQUINO, P., 1991. Theatrum politicum: The genealogy of capital, police and the state of pros- perity. In: The Foucault Effect: Studies in Governamentality (G. Burchell, C. Gordon \& P. Miller, ed.), pp. 104-118, Chicago: University of Chicago Press.

POTTER, J. \& WETHERELL, M., 1987. Discourse and Social Psychology: Beyond Attitudeand Behaviour. London: Sage Publications.

RENN, O., 1998. Three decades of risk research: Accomplishments and new challenges. Journal of Risk Research, 1:49-71.

SPINK, M. J. P., 1997. A Construção Social do Risco no Cenário da AIDS. Projeto Integrado. São Paulo: Conselho Nacional de Desenvolvimento Científico e Tecnológico. (mimeo.)

SPINK, M. J. P., 1998. A Centralidade do Conceito de Risco na Constituição da Subjetividade Moderna. Projeto. São Paulo: Fundação de Amparo à Pesquisa do Estado de São Paulo. (mimeo.)

SPINK, M. J. P., 1999. Risco el ncerteza na Sociedade Contemporânea: Vivendo na Sociedade de Risco. Projeto Integrado. Rio de Janeiro: Conselho Nacional de Desenvolvimento Científico e Tecnológico. (mimeo.)

SPINK, M. J. P., 2000a. A ética na pesquisa social: Da perspectiva prescritiva à interanimação dialógica. Psico, 31:7-22.

SPINK, M. J. P., 2000b. Risco e sociedade contemporânea: O papel da mídia na circulação dos repertórios sobre risco. In: A Construção Social do Risco no Cenário da Aids (M. J. P. Spink, org.), Relatório de Pesquisa, pp. 1-31, São Paulo: Conselho Nacional de Desenvolvimento Científico e Tecnológico.

SPINK, M. J. P., 2001. Os contornos do risco na modernidade reflexiva: Considerações a partir da psicologia social. Psicologia e Sociedade, 12:156-174.

SPINK, M. J. P. \& FREZZA, R. M., 1999. Práticas discursivas e produção de sentidos: A perspectiva da psicologia social. In: Práticas Discursivas e Produção de Sentidos no Cotidiano: Aproximações Teóricas e Metodológi cas (M. J. Spink, org.), pp. 17-39, São Paulo: Cortez Editora.

SPINK, M. J. \& MEDRADO, B., 1999. Produção de sentido no cotidiano: Uma abordagem teórico-metodológica para análise das práticas discursivas. In: Práticas Discursivas e Produção de Sentidos no Cotidiano: Aproximações Teóricas e Metodológicas (M. J. Spink, org.), pp. 41-61, São Paulo: Cortez Editora.

SPINK, M. J. P. \& MENEGON, V., 1999. A pesquisa como prática discursiva. In: Práticas Discursivas e Produção de Sentidos no Cotidiano: Aproximações Teóricas e Metodológi cas (M. J. Spink, org.), pp. 63-92, São Paulo: Cortez Editora.

TVERSKY, A. \& KAHNEMAN, D., 1981. The framing of decisions and the psychology of choice. Science, 211:453-458.

VON NEUMANN, J. \& MORGENSTERN, O., 1947. Theory of Games and Economic Behavior. Princeton: Princeton University Press.

WEEK, 2000. Thrill seekers or sound sleppers. Week, 29 apr:35.

WHITE, H., 1994. Trópicos do Discurso: Ensaios sobre a Crítica da Cultura. São Paulo: EDUSP.

WINTERTHUR INTERNATIONAL, 1998. Anúncio. Economist, 31 oct:56-57. 
Debate sobre o artigo de Mary J ane P. Spink

Debate on the paper by Mary J ane P. Spink

\section{Madel Teresinha Luz Risco, perigo e aventura na sociedade da (in) segurança: breve comentário}

Instituto de Medicina Social, Universidade do Estado

do Rio de Janeiro,

Rio de Janeiro, Brasil.

madelluz@uol.com.br

O artigo de Spink sobre risco coloca em jogo questões atuais de natureza teórico-metodológica e substantiva para as ciências sociais, que valem a pena mencionar, e na medida do possível, aprofundar, ainda que em "breve comentário", pretensão dessas notas.

A propósito da categoria de risco e seus usos diversos na contemporaneidade, que a autora designa como modernidade tardia, Spink desenvolve uma reflexão bastante densa sobre as relações entre linguagem, estrutura discursiva, produção de sentidos, suas funções e variações na cultura através da noção de repertório interpretativo. Variações que são de natureza histórica, é claro, mas também simbólica, expressas por meio de linguagem, ancoradas em discursos mais ou menos estruturados, relativos a grupos sociais, a saberes ou mesmo a formas de agir, a práticas. A complexa abordagem implicada na análise da autora supõe uma interdisciplinaridade em que antropologia, psicologia social, sociologia, história, genealogia e lingüística têm que andar de mãos dadas. A produção social de sentidos através da história, expressa em metáforas, palavras, conceitos, pode ser uma janela aberta para a compreensão das mudanças da sociedade, de seus momentos de rupturas, de continuidades, bem como da apreensão da direção dessas mudanças. Através da análise da transformação dos termos, dos conceitos, dos lugares comuns, das figuras de linguagem, enfim do que Spink designa como repertório interpretativo, é possível abordar, "a partir de um fenômeno específico", as profundas transformações em curso na cultura, atingindo talvez o mesmo tipo de percepção que Foucault (1966) evidenciou em sua obra As Palavras e as Coisas como a passagem de uma cultura da similitude a uma cultura da representação (modernidade clássica), quando pôs em foco o conceito de episteme, estabelecendo uma reflexão ainda hoje atual sobre a gênese das ciências humanas. Deste ponto de vista, o artigo de Mary Jane interroga essas ciências tanto do ponto de vista metodológico (como trabalhar em perspectiva interdisciplinar para desvendar surgimentos, evoluções e mutações na produção discursiva de sentidos?) como conceitual (qual o papel arquetípico das formações discursivas relativas a determinados termos, como o de risco, para entender as transformações culturais e sociais em curso?) Essas questões são em si mesmo inovadoras, e chamam a atenção para a interação entre a produção de sentidos, o imaginário social e as práticas sociais nas diferentes culturas.

Mary Jane Spink trabalha com o que podemos designar, parafraseando Isabelle Stenghers, como um operador conceitual, mais que um simples conceito, que éo de repertório interpretativo, que evidencia o papel estratégico da linguagem na sua abordagem, bem como com a análise de uma categoria que escolheu como "metáfora da modernidade tardia" - risco - significativa do momento de passagem de uma sociedade disciplinar para uma sociedade de risco.

A linguagem relativa ao risco é situada numa panorâmica sócio histórica dessas variações, vistas sob uma tripla dimensão do risco, entendido e analisado como forma de se relacionar com o futuro, como concei tuação e como gestão. O termo é focalizado desde sua emersão na cultura em termos de palavra (a questão da linguagem é, mais uma vez, a base do esclarecimento dos sentidos historicamente produzidos) no século XIV, em catalão, daí se espraiando para as línguas latinas e anglo saxônicas (século XVII), apontando para a idéia de eventos imprevisíveis no futuro, o qual passa a ser representado no imaginário social como controlável. A repertorização dos sentidos na história do termo risco é feita em perspectiva genealógica (no sentido foucaultiano), retraçando a evolução de sentidos de "fatalidade à fortuna", de hazard (perigo) - em francês acaso - à sorte e chance, no intuito de demonstrar a construção metafórica progressiva, dos sécuIos XII ao XVII, da categoria de risco, que setorna um dos conceitos básicos da modernidade clássica referidos ao futuro.

Por outro lado, o futuro concebido como um conjunto de eventos controláveis é próprio da lógica do capitalismo moderno, como nos ensinou Max Weber (1987) na Ética Protestante e o Espírito do Capitalismo. A objetivação do futuro como uma série de eventos ou operações controláveis éa ambição máxima da modernidade, tanto em termos de conhecimento ( "ciência moderna") como em termos de ação social ("ética do trabalho"). Spink nos refere como essa reflexão aparece em Bourdieu, que nos mostra como a incorporação da categoria de risco supõe uma "racionalização" da conduta e da vida em relação a um futuro abstratiza- 
do, cuja imprevisibilidade é mensurada (ou pelo menos "calculada"), evitando-se assim as “aproximações arriscadas e desinteressadas (...) de uma moral de generosidade", típicas de sociedades pré-capitalistas, segundo o sociólogo francês.

A passagem de termo a conceito envolveu a constituição de saberes estruturados na modernidade, como a matemática e a estatística (com o desenvolvimento da teoria da probabilidade), sua adoção como ciência de estado (séculos XVIII e XIX) até que o discurso estruturado na ciência sanitária como "gestão dos riscos" produziu no século XIX, segundo a autora, "o primei ro deslocamento no enredo arquetípico do discurso sobre o risco", passando, em termos de lingüística, da "metáfora à metonímia". Entretanto, apenas no século XX, segundo a autora, já em sua segunda metade, o risco, através da ciência epidemiológica, estruturou-se como um saber de gestão de riscos, gerando sofisticados modelos de análise, visando a calcular, controlar e/ ou prevenir riscos.

Esse modelo, que representa, segundo Spink, a passagem da metonímia à sinédoque da categoria de risco na sociedade contemporânea, gera um campo interdisciplinar de análise, prevenção e intervenção extensivo a áreas crescentes de conhecimento e atividade social, visando à percepção e gestão de riscos nessas áreas, e envolvem a economia, a saúde, a tecnologia e seus efeitos, a educação, as políticas públicas e, mais recentemente, a comunicação (uma vez que, segundo a autora "a participação pública (...) passou a ser el emento imprescindível no controlesocial dos riscos"). Entretanto, o modelo "global" de cálculo, prevenção e controle de riscos enfrenta duas questões até o momento insolúveis: a questão dos valores implícitos nos riscos (sua percepção, sua definição) e a questão da transformação da nature za dos riscos, progressivamente mais sistêmicos e globalizados. O que cria para tal modelo uma situação de "não controle" ou de passagem para um novo modelo, o da "gestão de riscos", que assinala, segundo Mary Jane Spink, a mudança de uma "sociedade moderna, disciplinar", em perspectiva foucaultiana, para uma sociedade de "modernidadetardia, de riscos".

No primeiro caso, da sociedade industrial capitalista, tratava-se de gerir e controlar a vida, basicamente das populações, o que trouxe à tona o conceito foucaultiano de biopoder, conjunto de estratégias disciplinares da docilização dos corpos para o trabalho, o que levou Foucault a elaborar por coerência o conceito de governamentalidade como mecanismo básico de gestão objetiva/ subjetiva da sociedade disciplinar. No segundo caso, temos um processo de deslocamento da gestão da vida para a gestão dos riscos, em que "globalização", "individualização e "reflexividade" como características básicas da modernidade tardia, implicam com a transnacionalização do capitalismo, em processos de "destradicionalização", de "singularização", sobretudo do que Spink designa como "ironia" nas estruturas discursivas, que mudam a natureza dos riscos, as estratégias de gestão dos riscos pelos indivíduos, e mesmo os mecanismos de gestão das populações, embora os relativos ao momento anterior da modernidade não estejam descartados. 0 mais importante a assinalar aqui talvez seja a mudança do próprio sentido de risco na cultura em função dos processos em atuação.

Do meu ponto de vista, a mutação discursiva mais significativa em relação a risco apontada no artigo, talvez seja a da conexão de risco e aventura em diversos setores das atividades sociais e dos valores culturais da atualidade: na economia, na educação, nas atividades empresariais, no esporte, nos jogos. O cultivo do risco como questionamento passa a ser associado à coragem, à bravura, à têmpera, à resistência, à disciplina, e mesmo ao espírito de equipe, à solidariedade focal. Spink associa essa conexão ao processo de globalização e aos efeitos destradicionalizantes e desterritorializantes do capitalismo transnacional, com a imponderabilidade sistêmica dos riscos tornando-se um impedimento ao seu controle e gestão, gerando novos sentidos metafóricos e novas práticas discursivas sobre o risco.

Estamos vivendo em uma sociedade onde emergem sentidos do risco como prática contínua de busca de rompimento dos limites humanos, inclusive da vida humana, isto é, como um arriscar-se, ou então como tentativa de controle do imponderável através do exercício obsessivo do cálculo de probabilidades em busca de "segurança" nos mais diversos campos da atividade social, sobretudo no econômico (é só refletir sobre a imponderabilidade e a vulnerabilidade crescentes das "apostas" da bolsa de valores). Talvez as novas práticas sociais e discursivas do risco estejam sinalizando para alguns sentidos implícitos a serem desvelados, como o de mimetismo da insegurança do sistema globalizado. Talvez estejam chamando a atenção, de forma paradoxal, para a incapacidade da sociedade atual de lidar com seus "riscos" mais evidentes: a dissolução de relações e instituições sociais tidas historicamente como permanentes, a enorme concentração de riqueza, a exclusão social crescente como bola de neve, a fragilidade de uma eco- 
nomia mundial interdependente que se assemelha a um grande jogo de azar. A busca de segurança em meio à prática do risco (como ilustra a imagem citada do operário sentado em uma viga no alto da construção, "dominando o mundo" de suas alturas) talvez sinalize, como um sentido "sintoma", que a segurança supõe, paradoxalmente, uma constante exposição ao risco, como exposição ao perigo de vida. A leitura do artigo de Mary Jane Spink, apesar de instigante, não nos deixa em posição confortável quanto ao futuro da cultura atual, quanto aos sentidos que está gerando, ao menos no que concerne à noção de risco e futuro.

FOUCAULT, M., 1966. Les Mots et les Choses - Une Archeologie delas Sciences Humaines. Paris: Gallimard.

WEBER, M., 1987. A Ética Protestante e o Espírito do Capitalismo. 5a Ed. São Paulo: Pioneira.

Edinilsa Ramos de Souza

Centro Latino Americano de Estudos deViolência e Saúde Jorge Careli, Departamento de Epidemiologia e Métodos Quantitativos em Saúde Escola Nacional de Saúde Pública, Fundação Oswaldo Cruz, Rio de Janeiro, Brasil. edinilsa@claves.fiocruz.br

\section{Quando viver é o grande risco-aventura}

Antes de tecer qualquer consideração, quero dizer do meu contentamento em debater o presente artigo, que traz importante contribuição à reflexão filosófico-científica no tema abordado.

O artigo é profícuo e dá margem a uma série de questões, mas gostaria de me ater, inicialmente, a uma delas. Mais precisamente, quero questionar sobre um ponto que me chamou a atenção no título, que foi o uso da partícula na modernidade tardia, dando a entender que haveria outras metáforas possíveis no período referido, ao invés da conotação de que o risco-aventura seria, por excelência, a metáfora da modernidade tardia, o que parece ser a tônica do artigo. Gostaria, portanto, que a autora explicitasse suas idéias em relação à essa questão.

Esperei ao longo de toda a leitura, que a abordagem do risco no campo da saúde pública fosse aprofundada. Sendo essa minha área de atuação e a da revista na qual o artigo está sendo publicado, confesso que me senti um pouco frustrada no desejo de ver o conceito em questão mais discutido nessa área do conhecimento.

A partir da leitura, fiquei tentada a fazer um exercício reflexivo, aplicando algumas das teses defendidas no artigo, ao tema específico da violência em um grupo particularmente vitimizado por esses eventos - os jovens.
Nas sociedades contemporâneas os jovens têm sido as principais vítimas da violência, apresentando elevadas taxas de morbimortalidade devido às suas mais diversas formas - homicídios, suicídios, agressões não fatais, maus tratos, negligência, dentre outras. Essa vitimização de jovens, tem se apresentado de modo globalizado, tal qual alguns dos fenômenos discutidos no artigo, mesmo que em sua dinâmica atuem fatores regionais ou locais específicos, como lembra Michel Wieviorka (1997) em seu texto O Novo Paradigma da Violência, no qual o autor busca explicá-la no mundo moderno. O caso do narcotráfico exemplifica bem as idéias desse autor. Dentre os fenômenos infra-políticos identificados por ele, o narcotráfico constitui uma atividade ilegal e criminosa global, mas que tem particularidades no seu processo de produção, distribuição e comercialização inter e intra países. E esse fenômeno tem envolvido principalmente uma parcela da população jovem.

No caso da violência contra os jovens, os estudos têm consolidado resultados que indicam que as principais vítimas são os mais pobres, com baixa ou nenhuma escolaridade e qualificação profissional, provenientes de famílias constituídas por mulheres chefes de família, com baixa renda e residentes nas periferias das grandes áreas urbanas. É também nesses mesmos espaços sociais de onde costumam ser recrutados para o exercício de atividades ilegais e criminosas, engrossando as crescentes estatísticas de infrações por eles promovidas e tornando frágil e volátil a linha divisória entre a legalidade e a ilegalidade.

Trata-se, portanto, de um grupo que para conseguir usufruir, minimamente, dos benefícios das sociedades de consumo precisa assumir riscos. E esses riscos são assumidos por ele, seja pela mera aventura da busca de sentido e prazer na vida, seja porque é a única forma possível de sobreviver e ter algum direito, sobretudo ao reconhecimento, ao respeito no interior de seu grupo e ao consumo, mesmo que conseguido de modo ilegal e violento. Nesse caso, percebe-se que o risco assume o significado de atributo individual, comumente adotado pela epidemiologia (enquanto probabilidade de sujeitos sofrerem danos ou agravos à sua saúde devido ao comportamento de se expor a determinado fator). Por outro lado, também não se pode negar a existência de fatores que transcendem à vontade desses sujeitos e que transformam o risco em algo para além dos comportamentos e desejos individuais. Esse risco é então abordado como uma vulnerabilidade própria de certos grupos ou espaços sociais espe- 
cíficos, como querem os cientistas sociais e os estudos epidemiológicos de âmbito ecológico. Trata-se de um risco que significa uma exposição a determinado(s) fator(es), independente da vontade de se expor individualmente a ele(s). Em outras palavras, encontram-se sob risco devido a circunstâncias particulares de vida - como pertencer a determinado grupo social ou residir em determinada comunidade - mesmo que não tenham a intenção, sequer inconsciente, de se expor. Como afirma J. L. Vethencourt (1990) em trabalho intitulado Psicología dela Violencia, muitos desses jovens, certamente, jamais "optariam" (grifo meu) por se arriscar em situações violentas se tivessem outras possibilidades e condições de vida.

Transpondo o pensamento da autora para esta reflexão, tendo a concordar que a violência que hoje vitimiza os jovens, é também expressão da destradicionalização de instituições como a escola, a família e a religião. Tratar-seia de um processo inverso àquele identificado por Chesnais (1981) em seu livro Histoire dela Violence, no qual a constituição de instituições como a escola e a polícia, em determinada época histórica, foi paulatinamente garantindo os direitos de cidadania e o controle da criminalidade em países da Europa. A meu ver, a destradicionalização de certas instituições, sobretudo em sociedades capitalistas tardias, como é o caso do Brasil, está se dando sem que direitos básicos tenham sido sequer conquistados. Em outras palavras, já se destradicionaliza o que sequer chegou a se consolidar plenamente nas democracias mais recentes.

Hoje, pensar a situação do jovem nas sociedades contemporâneas, significa buscar compreender as situações de exposição a riscos e/ ou vulnerabilidade, como queiram os especialistas de diferentes áreas do conhecimento, e se indignar com o fato de que cerca de sete em cada dez jovens estão morrendo por uma causa violenta, como acontece nas grandes metrópoles brasileiras.

É preciso admitir que existe uma parcela de jovens que não "escolhe" o risco-aventura dos esportes radicais. Para eles, viver éo grande riscoaventura. Em meio às mais inóspitas condições, esse risco-aventura é cotidiano e até por isso mesmo banalizado, seja no uso da arma de fogo real como brinquedo, seja na quase indiferença diante da morte freqüente de amigos e parentes.

Portanto, é para este grupo que se precisa aprofundar o con hecimento, visando a políticas alternativas e integradoras, sobretudo de inserção de camadas cada vez mais si gnificativas de jovens. O artigo em debate, certamente, tem uma contribuição a dar nessa reflexão.

CHESNAIS, J. C., 1981. Histoire dela Violence. Paris: Robert Laffont.

VETHENCOURT, J. L., 1990. Psicología de la violencia. Gaceta de la Asociación de Profesores de la Universidad deVenezuela, 62:5-10.

WIEVIORKA, M., 1997. O novo paradigma da violência. Tempo Social, Revista de Sociologia da USP, 9:5-41.

Luís David

Castiel

Departamento de Epidemiologia e Métodos Quantitativos em Saúde, Escola Nacional de Saúde Pública, Fundação Oswaldo Cruz, Rio de Janeiro, Brasil. castiel @ensp.fiocruz.br

\section{Ariadne, Dédalo e os bondes do tigrão}

Nesta tentativa de contribuição ao debate, espero fazer jus ao nível de qualidade e de pertinência alcançados pela Professora Mary Jane Spink ao apresentar e desenvolver idéias e conteúdos muito bem articulados em seu belo artigo. Em função de maior convívio com uma disciplina riscológica por excelência, inicio o comentário com o foco sobre a epidemiologia. Mais, especificamente pretendo ressaltar o próprio aspecto discursivo - metafórico, encontrado no conceito de risco. Considere-se, por exemplo, o fato de não ser costumeiro o emprego das designações "grande/ pequeno", "forte/fraco" ou mesmo, "muito/pouco" para indicar as características do risco, conforme sua quantificação.

$\mathrm{Na}$ verdade, os adjetivos utilizados nestas circunstâncias estão vinculados à idéia de verticalidade: "alto/ baixo risco". Estes se baseiam no conceito metafórico (comum a outros conceitos científicos): “mais é em cima; menos é embaixo", baseado na representação visual dos aspectos quantitativos em questão, sob o ponto de vista de um "empilhamento" (como se aparece em determinados gráficos).

Este conceito metafórico orientacional foi delineado por Lakoff \& Johnson (1980). Os autores esclarecem que sua formulação, tal como apresentada, é limitada, pois não assinala a inseparabilidade das metáforas de suas respectivas bases experienciais. Estas, por sua vez, podem variar, mesmo em outras metáforas relativas à verticalidade. No caso de, por exemplo, "saúde e vida é acima, doença e morte é abaixo", a base experiencial parece ser a posição corporal que acompanha estes estados/ condições.

Mais relevante ainda é a constituição do conceito de risco como uma peculiar metáfora ontológica, ou seja, enquanto entidade virtualmente detentora de substância. Ao trazerse substância ao risco, este pode ser objetiva- 
do, e assim, delimitado em termos de possíveis causas que, por sua vez, podem ser decompostas em partições. Esta operação estatística permitiria respectivas quantificações e eventual estabelecimento de nexos - associações, correlações.

O indivíduo, ao se expor a supostos "fatores de risco", faz com que o risco, entidade incorpórea, passe a ter a propriedade de se materializar sob sua forma nociva - que pode ser denominada agravo (entre várias outras designações), numa operação semântica equivalente a que demarca doença em sua acepção metafórica ontológica. Só que, neste caso, os riscos "existiriam", por um lado, como potenciais invasores de corpos. Mas, por outro, a ambiência metafórica deste mundo virtual e fantasmático dos riscos poderia adquirir visibilidade (e, portanto, concretude) nos resultados de exames imagéticos/ testes laboratoriais indicativos dos efeitos da exposição a fatores de risco. Por exemplo, presença/ ausência de displasia mamária ou taxas elevadas do colesterol (especialmente LDL - o ruim...) ou ainda, mais modernamente, nas testagens gênicas para câncer de mama.

Mas não é necessária a corroboração médico-laboratorial para instituir a "visibilidade/ presença do risco". Basta ser obeso ou apresentar trejeitos supostamente relacionados ao comportamento homossexual, para ser virtualmente incluído em determinadas condições encaradas como mais vulneráveis (Castiel, 1996).

Agora, antes de prosseguir, é preciso deixar explicitado meu intento (talvez despudorado...) de imitar o bem sucedido expediente empregado por Spink. Ou seja: também utilizar exemplos oriundos da imprensa leiga (e também da literatura). Na edição latino-americana do conhecido semanário Time de 6 de setembro de 1999, a reportagem de capa mostrou um montanhista pendurado em uma rocha com uma paradoxal fisionomia, aparentando um misto de deleite e esforço físico. A chamada enunciava: "Why we take risks. From extreme sports to un protected sex, thrill is becoming more popular (...)". Localizado na seção apropriadamente chamada "Aventura" - junto ao título do texto, Life on theEdge, segue o subtítulo perguntando se a vida cotidiana está ficando muito enfadonha (dull) e porque, então, americanos buscam (seek) o risco como nunca antes (Greenfeld, 1999). Há, em síntese, uma detaIhada descrição de muitas modalidades de esportes ditos extremos (ou radicais) incluindo corridas de Fórmula 1, de atividades ligadas a investimentos financeiros de risco em bolsas e mercados, de profissões que lidam com emer- gências - neuro-cirurgiões, bombeiros (soldados do fogo). O texto encerra sugerindo que “sem al guma expressão de risco as pessoas podem nunca conhecerem seus limites e portanto quem são como indivíduos".

Há na matéria tentativas de explicar o fenômeno. Entre elas, referências ao best seller de Peter Bernstein sobre risco. Deste, um comentário é destacado: para todas estas "coisas" acontecerem é preciso um particular tipo de ambiente. Tal ambiente enfatiza a presença da grande prosperidade norte-americana e a ausência de guerra envolvendo a participação direta dos Estados Unidos por mais de uma década. Difícil avaliar o grau de pertinência destas afirmações. A reportagem inclui um inevitável teste avaliativo - quiz - da capacidade de se expor a riscos, elaborado pelo psicólogo entrevistado no texto - Frank Farley da Temple University. Este, por sua vez, postula que correr riscos conscientes envolve superar instintos e sugere a existência de uma personalidade tipo T - risk takers (com subtipos: T físico - atletas extremos, T intel ectual - grandes cientistas...). E conclui (suponho que com regozijo) com uma extrapolação ao afirmar que os Estados Unidos são uma nação tipo T. O espaço disponível e o propósito deste comentário obrigam que evitemos entrar no mérito dessas proposições...

No Brasil, a editora L\&PM lançará no verão de 2001 uma sintomática coletânea chamada Prazeres eRiscos (Machado, no prelo) - livro irregular, mais estilo "Ieitura de bordo", que mescla pequenos textos de autores clássicos e contemporâneos de níveis bastante desiguais sobre aspectos diversos que envolvem tal temática. Cícero (velhice), Baudelaire (vinho), Balzac (mulher de 30 anos), Dostoievsky (jogo) são agrupados com Millor Fernandes (cidadania) mas também com um cirurgião cardíaco, jornalistas de Fórmula 1 e de culinária, um especialista profissional em incursões por regiões inóspitas (prazeres e riscos da aventura), entre outros.

Revista Veja - edição de 25 de abril de 2001. Matéria sobre tigres como animais de estimação nos Estados Unidos e uma menção a um empresário alemão naturalizado brasileiro que cria um tigre de Bengala de quatro anos na sua fazenda em Santa Catarina. Diz ele: "É um desafio, e sem desafios a vida não tem graça" (Veja, 2001:76). O tigre habita uma área de três hectares, com cachoeira artificial (costuma banharse com freqüência) e come cinco quilos de carne por dia, podendo chegar a sete, quando ficar adulto.

Estas vinhetas servem, de certa forma, para se juntar aos exemplos apresentados pela au- 
tora. No entanto, elas pretendem ir além e enfatizar a impressão, salvo equívoco, de todas referirem-se, na maior parte das vezes, a um ponto de vista específico que se reitera ao longo dos exemplos, acentuadamente marcado pelos signos do acesso aos mercados e da participação nos processos consumidores. Da mesma forma, muitos dos autores que sustentam teoricamente as postulações de Spink, parecem pertencer e analisar contextos equivalentes a partir de seus lugares de scholars, em geral, no lado de cima do Equador. Então, creio caber uma pergunta: "quanto" de suas proposições permanecem sustentáveis e válidas para o lado de baixo dessa imaginária linha? Totalmente? Parcialmente? Alguns determinados aplicáveis a contingências específicas? Quais?

Para seguir adiante, em uma inflexão metafórica, vamos "amplificar" o felino mencionado anteriormente e fazer referência ao dito movimento funk originário das favelas do Rio de Janeiro. Houve grande visibilidade (e audibilidade) nacional nesse primeiro verão do novo século, com músicas de batida eletrônica repetitiva e letras de duplo sentido (às vezes nem tão duplo assim...) com fortes conotações sexuais. A música emblema ("vou passar cerol na mão, assim, assim" etc...) foi confeccionada pelo conjunto autodenominado Bonde do Tigrão, ou seja: um grupo de jovens do sexo masculino dispostos em ritmo de aventura, de preferência sexual.

Uma das celeumas ligadas a tal movimento foi trazida pela divulgação da ocorrência de relações sexuais desprotegidas (eventualmente múltiplas) no salão, no decorrer dos bailes. As moças já viriam "preparadas" para essa possibilidade, ou seja, desprovidas de vestes íntimas para uma suposta "facilidade de acesso". Essas circunstâncias seriam responsáveis por engravidar e possivelmente contaminar com doenças venéreas de distintos tipos e gravidade diferenciada. Algo talvez não diferente de muitos bailes de carnaval, quando ocorrem situações onde vigoram estados euforizantes, propícios a excessos/transbordamentos de várias ordens.

Ainda assim, não parece tão simples compreendermos o repertório de significados envolvidos nessa e em outra formas de exposi ção a riscos. Em particular, seriam aspectos do risco-aventura no mesmo registro que as "formas corrompidas dos ilinx modernos na perspectiva do ordálio" a partir de Le Breton, referido por Spink? E/ ou, em termos mais gerais, como aspectos ligados à globalização, à individualização e à reflexividade da sociedade de risco na modernidade tardia, tais como sugeridos por Ulrich Beck?
Beck, assinalado no texto como referência fundamental, postula a complexidade e a natureza sistêmica (meu sublinhado) dos riscos modernos - "riscos manufaturados, produtos dos desenvolvimentos da ciência e da tecnologia" (Beck, 1993, apud Spink). No entanto, como salienta Lupton (1999), as representações de Beck (e, de certa forma, também de Giddens) podem ser consideradas excessivamente especulativas, tratando mais de processos estruturais e organizacionais, sem incluí-los de modo suficiente especificamente nos processos reais e experiências da vida cotidiana e institucional. Pode-se, ainda, argumentar que Beck e Giddens em sua ênfase na individualização não dedicam um reconhecimento suficiente quanto a aspectos simbólicos compartilhados do risco, sejam comunais, sejam estéticos.

A reflexividade não está apenas baseada em avaliações de caráter cognitivo, mas também depende de interpretações, vinculadas a dimensões sócio-culturais ainda localizadas, mesmo em meio a processo desterritorializantes. As respostas ao risco são também desenvolvidas mediante a pertença das pessoas a grupos e redes sociais, o acesso a recursos materiais e $a$ inclusão/ exclusão nas relações de poder.

A exemplo da figura mitológica, mescla de humana e deusa, Ariadne- Beck e Giddens procuram nos orientar no interior do labirinto (inclusive dos riscos) da modernidade tardia (Castiel, 1999). Mas, neste caso, creio que o próprio Dédalo (que instruiu Ariadne a usar o fio condutor para permitir Teseu encontrar a saída do labirinto após matar o Minotauro) tem dificuldades para compreender as cambiantes dimensões e formas desse labirinto tardo-moderno que se reconfigura autonomamente sem cessar. Poderia Ariadne nos ajudar a escapar dos alto-falantes do grande labirinto midiático onde tonitroa o onipresente Tigrão que não parou de nos acossar nos últimos tempos? Em outros termos, como lidar com a pletora de novos e excessivos signos que decerto continuarão a ser gerados e, feito almas penadas, sairão à cata de significados para depois desaparecerem rapidamente, como ocorre nestes tempos simultaneamente proliferativos e evanescentes?

Latour (1999) refere-se ao mito de Dédalo para estudar o "coletivo de humanos e não-humanos" (forma com que o autor evita se referir à "sociedade" e a "sujeitos" e "objetos", por esses termos manterem vínculos com proposições modernistas) constituído cada vez mais por artefactos técnicos e por suas interconexões labirínticas com os humanos. Dédalo representa bem a sinuosa configuração do saberfazer técnico para além do caminho retilíneo 
da razão e do conhecimento científico. Dédalo também é outra forma de designar o "Iabirinto" com suas curvas inesperadas, obrigandonos a dar guinadas ao percorrer seus desvios.

De modo bastante abreviado, nossos tempos labirínticos se caracterizam pela produção incessante e engenhosa de novas tecnologias e correspondentes repercussões na ampliação e na velocidade de circulação das trocas econômicas, na proliferação de estratégias de mediação comunicacional, na multiplicação e diluição das matrizes identitárias, no clima generalizado de ambiguidade quanto às perspectivas de orientação em curto prazo e na crise de sentido.

A respeito desse último aspecto, uma aguda observação de Georges Balandier (1999) merece ser mencionada para ilustrar a problemática de estudar-se temas fugidios que dão margem a polêmicas e permitem distintas abordagens, eventualmente antagônicas. O etnólogo francês enfatiza a grande fragilidade das palavras quando se tenta explicar esses tempos vertiginosos. O vocabulário disponível consegue apreender precariamente tão-somente partes limitadas do que acontece ao nosso redor. Mas logo, de modo difuso, um aspecto fragmentário, metonímico é confundido com o todo, tornando-se referência até ser substituído rapidamente por outro.

O grande problema, deste modo, é que essas construções não podem ser consideradas como sendo verdadeiras ou falsas. Pois, de alguma forma, referem-se a porções "reais" do que existe. Mas, ao mesmo tempo, seu recorte é, muitas vezes, tomado não só como representante fidedigno do todo, mas como sendo o próprio “todo". Enfim, temos de admitir, a priori, que operamos cada vez mais com conceitos e idéias precárias e sujeitas a controvérsias e imprecisões (Castiel, 2000).

Sem dúvidas, o estimulante texto de Spink propicia, com extremo vigor, tanto reflexões como indagações a respeito dos estranhos e ambivalentes tempos em que vivemos. Estranheza e ambivalência abordada por vários pensadores - Ariadne, onde se destaca especialmente Zygmunt Bauman.

Acredito valer a pena citá-lo mais detidamente: “( $n$ )o mundo pós-moderno de estilose padrões de vida livremente concorrentes, há ainda um severo teste de pureza que se requer seja transposto por todo aquele que solicite ser ali admitido: tem demostrar-se capaz de ser seduzido pela infinita possibilidadee constante renovação promovida pelo mercado consumidor, dese regozijar com a sorte de vestir edespi r identidades, de passar a vida na caça interminável de cada vez mais intensas sensações e ca- da vez mais inebriante experiência. Nem todos podem passar nessa prova. Aqueles que não podem são a ‘sujeira' da pureza pós-moderna. (...) (O)s deixados de fora como um problema são consumidores falhos - pessoas incapazes de responder aos atrativos do mercado consumidor porque Ihes faltam os recursos requeridos, pessoas incapazes de ser 'indivíduos livres'(...)" (Bauman, 1998:23-24).

E eu acrescentaria: impossibilitados de escolher e bancar sua inclusão nos afluentes e múltiplos jogos de risco-aventura possíveis, proporcionados pela modernidade - ainda que tardia. Algo situado para além do ruído causado pelos bondes dos tigrões ou de outras atividades de risco impuras - como o surfe ferroviário ou pior ainda, a participação nos escalões inferiores do narcotráfico.

BALANDIER, G., 1999. O Dédalo. Para Finalizar o Século XX. Rio de Janeiro: Editora Bertrand Brasil. BAUM AN, Z., 1998. O Mal-Estar da Pós-Modernidade. Rio de Janeiro: Jorge Zahar Editores.

CASTIEL, L. D., 1996. Moléculas, Moléstias, Metáforas. O Senso dos Humores. São Paulo: I-Editora «tttp: // www.ieditora.com.br>.

CASTIEL, L. D., 1999. A Medida do Possível. Saúde, Risco e Tecnobiociências. Rio de Janeiro. Editora Contracapa/ Editora Fiocruz.

CASTIEL, L. D., 2000. Dédalo dentro do dédalo? Identidade cultural, risco e promoção de saúde. In: VI Congresso Brasileiro de Saúde Coletiva - O Sujeito na Saúde Coletiva, Anais, CD-ROM, Salvador: ABRASCO.

GREENFELD, K. T., 1999. Life on the edge. Time, 153:16-20.

LAKOFF, G. \&JOHNSON, M., 1980. Metáforas dela Vida Cotidiana. Madrid: Cátedra.

LATOUR, B., 1999. Pandora's Hope. Essays on the Reality of Science Studies. Cambridge: Harvard University Press.

LUPTON, D., 1999. Risk. Key Ideas. London: Routledge.

MACHADO, I. P. (ed.), no prelo. Prazeres e Riscos. Porto Alegre: $L \& P M$.

VEJA, 2001. Bando de tigrões. Veja, 1697:76. 
Maria Helena Cabral de Almeida Cardoso

Instituto Fernandes Figueira, Fundação Oswaldo Cruz, Rio de Janeiro, Brasil.

oscarmc@unisys.com.br

\section{O risco-aventura e os limites de uma teoria da história}

O risco-aventura como metáfora na (da) modernidade tardia, desde o início da leitura do exercício de translocação conceitual empreendido por Mary Jane Spink, remeteu-me à noção de uma sociedade que, muito mais do que a nomeada por Beck (1992), para além do poder disciplinar, advoga a si a delimitação da trajetória do homem, modulando seu tempo e sua vivência pessoal. É como se a sempre presente pergunta de Gauguin: "de onde viemos, quem somos, para onde vamos?" - fundamento de nossa historicidade - estivesse respondida, não mais através de respostas múltiplas, diferentes em substância e estrutura, mas num sentido quase linear e especificado: viemos de uma herança genética codificada, que conjugada com os fatores de risco nela compreendidos e aqueles adquiridos, nos molda, e encaminhamos para uma morte passível de ser probabilisticamente datada se tais riscos forem considerados e administrados. Fica implícita que a fase intermediária - "o quem somos" - permanece ligada, talvez como jamais o fora, à idéia de liberdade, só que esta liberdade, agora, não está mais numa condição de "essência", como pensavam os iluministas, mas qualificada pela marca da opção e da escolha embutidas na "aventura" de viver. O que se pauta não é o reforço do conceito de livre arbítrio, pois nele se inscreve uma percepção teológica de mundo, mas a de liberdade/ aventura perante a vida e a morte. Não é mais Deus quem fez os homens e esses, porque dotados de livre arbítrio, seguem ou não Seus desígnios. A escolha que atualmente se patenteia é de outra ordem. Não somos dotados de livre arbítrio porque não há quem sobre nós tudo sabe; somos, isso sim, dotados de liberdade de opção e escolha de conduzir a "aventura" de nossas vidas, mediante a gestão das informações sobre todos e quaisquer riscos estudados, medidos e nomeados. Essa ilusão nos é vendida dentro das fronteiras de um mercado alicerçado numa ordem social que, na falta de uma reflexão mais profunda, eu chamaria de ordem social da imagem mediática.

E o que tal ordem parece pretender? Para mim é claro e, a própria argumentação levada a cabo no texto de Mary Jane Spink, referendaa. Trata-se, como diz um dos personagens da série Arquivo $X$, de "inventar" o futuro para meIhor controlá-lo. Mas, se somos assolados, na atualidade, por uma certeza de que algo mudou, de que há muito viemos sofrendo trans- formações de algum modo decisivas e de que nossa vertiginosa história tecnológica do presente modula novas formar de sentir, essa história, por outro lado, remete-se para a produção de novos sentidos que nos permitem outras e mudadas interpelações com o mundo e seu conteúdo. Assim, é necessário abrir-se para as surpresas, para a heterogeneidade, para múltiplas semioses e se isso pode ser qualificado como aventura, então, bem vinda ela seja.

Uma teoria da história que considere e se preocupe em oferecer instrumental para uma prática crítica capaz de reconhecer as próprias "tecnologias semióticas" (Haraway, 1999) do homem para a fabricação de sentidos, talvez mais que constatar uma sociedade de risco a Beck, enseje refletir sobre o núcleo dela, ou seja, a questão da vigência atual de sociedades de controle, conforme o delineado por Deleuze (1992) e dentro delas pensar a ética da ação humana, sobretudo, na transformação do caminho ditado pela metáfora do risco-aventura. É voltar-se para o "quem sou?" Pensar o ser hodierno relacionado a um corpo que é ao mesmo tempo propriedade e produto (Vaz, 1996). Propriedade porque é resultado de uma identidade construída pelo consumo e pela realidade de que cada um de seus órgãos são matériaprima/ produtos colocados à disposição de novas tecnologias.

Entretanto, pensar a ética da ação humana, dentro dessa nova realidade do corpo é também, no meu entender, não abdicar de um projeto de (re)atualizar a vontade de utopia interligada ao desejo e à necessidade, porque sem ele não há como (re)equacionar o viver societário e, principalmente, as dimensões assustadoras assumidas pela fome e pela miséria em escala mundial. A democracia social deve permanecer no horizonte assim como a luta contra o esvaziamento do processo político. Tanto a transmutação para a política do corpo, quanto a assunção do risco-aventura como metáfora na (da) modernidade, parece-me, funcionarem mais como símbolos do que signos/ sinais da realidade que se deseja/ precisa mudar. Se enquanto símbolos escapam, em parte, a um projeto de racionalismo totalizador, por outro lado não podem se limitar à mera constatação de um determinado modo de se apropriar do mundo. Nesse sentido, faz-se necessário empreender uma ética de valorização da ação humana que precisa da materialidade histórica de uma razão afetiva.

A aventura não seria, então, aquela embutida nos repertórios interpretativos do risco, mas uma semelhante ao do camponês de uma "estória" sempre contada por Cornelius Casto- 
riades em suas conferências (Heller, 1993). A "aventura" deste camponês era a do viver plantando oliveiras para seus netos, pensando no quanto eles iriam usufruir do horto, o que fazia, segundo ele, não por desprendimento, mas sim por prazer, porque via os arbustos crescerem. Do risco-aventura, enquanto plot de uma meta-narrativa sobre a tardo-modernidade, se pensássemos como o camponês de Castoriades, passaríamos à aventura ética de plantar, mesmo sem a certeza de que alguém irá fazer uso daquilo que plantamos, todavia podendo desejar que alguém o faça. No caso não seria considerar o risco como ator histórico e, sim, considerar e aceitar a história como risco.

BECK, U., 1992. Risk Society: Towards a New Modernity. London: Sage Publications.

DELEUZE, G., 1992. Conversações. Rio de Janeiro: Editora 34.

HARAWAY, D., 1999. Situated knowledges. In: The ScienceStudies Reader (M. Biagioli, ed.), pp. 172-188, New York: Routlegde.

HELLER, A., 1993. Uma Teoria da História. Rio de Janeiro: Civilização Brasileira.

VAZ, P., 1996. O Corpo-Propriedade. Rio de Janeiro: Programa de Pós-Graduação em Saúde da Criança e da Mulher, Instituto Fernandes Figueira. (mimeo.)

José Ricardo de Carvalho Mesquita Ayres

Departamento de Medicina Preventiva, Faculdade de Medicina, Universidade de São Paulo, São Paulo, Brasil . jrcayres@usp.br

\section{Risco e imponderabilidade: superação ou radicalização da sociedade disciplinar?}

É sempre um grande prazer e, na mesma medida, um desafio debater as contribuições conceituais que a Professora Mary Jane Spink tem trazido para o campo da saúde e das ciências sociais. No presente artigo, Spink nos deixa, uma vez mais, diante de uma série bastante rica e complexa de questões. Entre os diversos aspectos levantados, será necessário, claro, fazer um recorte que torne possível o diálogo no limitado espaço destinado a esses comentários. Nesse sentido, procurarei deter-me, fundamentalmente, na tese da transformação, na idéia de que, por trás das mudanças que a palavra risco foi experimentando ao longo de sua vida discursiva, existe uma ruptura significativa de condições/ exigências de validade no horizonte normativo da modernidade.

A proposta de reflexão do artigo parte de um claro móvel prático: o desafio, ao mesmo tempo técnico, teórico-filosófico e ético, de identificar as novas formas de sensibilidade social da chamada modernidade tardia, trazendo para o exame público, de forma mais positiva e livre, o modo como estamos, ou podemos estar, construindo nossa sociabilidade. Aponta, nesse sentido, para uma mudança importante, que seria o abandono de uma normatividade de caráter disciplinar, fixadora de regras, para outra, de caráter apenas regulador, criadora e disseminadora de subsídios para a tomada de decisões. Acrescenta a essa formulação a idéia de que, em oposição à primeira, de tendência mais organizativa-conservadora, este horizonte normativo recente seria mais vinculado à ação, à aposta, ao enfrentamento do imponderável, o "risco-aventura”.

Estou de acordo com a posição, solidamente sustentada pela autora, de que as sociedades modernas transitaram de formas de sociabilidade mais fortemente apoiadas numa contratualidade explícita, disciplinar, para outras, onde os modos de pactuar e exercer a coerção social estão distribuídos de forma pulverizada e internalizada nos indivíduos. Também concordo que o risco é, efetivamente, um elemento fundamental para essa passagem. Resta então, o desafio, proposto pela autora, de avaliar criticamente o significado desse "risco-aventura" nas sociedades ditas "pós-modernas".

Pensada em relação ao móvel ético de uma sociedade solidária, livre e criadora, o que significa a penetrante idéia de gestão de riscos? De que "aventura" estamos falando quando sinalizamos positivamente o "expor-se a danos" por ousar, por fazer acontecer, desqualificando como "sonolenta" a opção por não correr riscos? Os exemplos trazidos pela autora me parecem muito fecundos em mostrar alguns elementos discursivos comuns e bastante poderosos. Fala-se do indi víduo quando se fala em gestão de risco, não de grupos, muito menos de comunidades - e a imagem (não autorizada) do operário solitário em plena megalópole é aqui emblemática. Mais, esse indivíduo é concebido sempre contra o pano-de-fundo de um meio hostil, desconhecido, no mínimo desafiante, no qual ele tem de vencer, vencer por sua ousadia, por sua coragem, por sua capacidade de ação. Para completar a "sagrada" trindade, a figura redentora de uma mercadoria sempre uma tecnologia, um saber fazer - que garante que, afinal, esse indivíduo prevaleça, seja preservado, tenha... segurança(!).

Não sei se exagero no pessimismo, mas atentando bem para esse discurso, não me parece difícil reconhecer o "velho e bom" darwinismo social. Meio eclipsada a certa altura do século $X X$, pela maré vermelha das revoluções 
socialistas, ou pelo brilho caro do Estado do bem-estar social, a perspectiva ideológica da existência como atualidade da saga particular dos indivíduos (tecnologicamente) mais competentes parece cruzar toda a Modernidade, desde o período clássico - com as promessas onipotentes das Luzes - até o nascente século XXI - com sua extraordinária capacidade de processar probabilidades. Mesmo quando no matricial pensamento bio-evolucionista, a idéia de competição indivíduo-meio-indivíduo já está largamente superada, prestando-se mais e mais atenção para a interdependência e a cooperação na transformação das formas de vida como ideologia social, o darwinismo parece ainda muito vivo e eficaz. É como porta-voz dessa ideologia que a onipresença e a onipotência mercadológica do discurso do risco me parece mais compreensível. Nem liberdade, nem criatividade: faça-se, sem pensar; faça você e consuma o "como fazer" (tecnó-logos) para ser vitorioso. Portanto, disciplina ainda, a pior delas, aquela cuja finalidade conhecemos cada vez menos e contra a qual se torna mais e mais difícil se rebelar, à medida que ela vai se tornando menos e menos visível e, portanto, menos acessível ao pensamento, conforme o diagnóstico “melancólico" dos Frankfurtianos.

Mas não se preocupe a autora, que o efeito da reflexão que tão agudamente nos traz com seu artigo, não me leva a um diagnóstico fatalista e paralisante. Ainda com a Escola de Frankfurt, vejo no pessimismo filosófico apenas a outra face de um otimismo prático incorrigível (espero). É que, até onde consigo pensar a questão, se não estivermos atentos para o "risco-espetáculo" - tão bem representado por No Limite, recente sucesso de Ibope - atrás, através e para além do risco-aventura, vamos apenas continuar perdendo vidas jovens nos esportes radicais (esses sim, sem qualquer possibilidade de cálculo e gestão de danos) e podemos perder chances preciosas de pensar o indivíduo como o inseparável par "eu-outro", de conceber a felicidade não "contra o mundo", mas "no mundo e pelo mundo" e de construir o conhecimento não como simples mercadoria para consumo de êxitos técnicos mas, fundamentalmente, como poética social de sucessos práticos.

\section{Si mone Montei ro, Naturalização do risco:} Elizabeth

Moreira dos Santos

Instituto Oswaldo Cruz Fundação Oswal do Cruz, Rio de Janeiro, Brasil. msimone@ioc.fiocruz.br

Departamento de Endemias Samue Pessoa, Escola Naciona de Saúde Pública, Fundação Oswaldo Cruz, Rio de Janeiro, Brasil. bmoreira@ensp.fiocruz.br

\section{do molde à modulação?}

A estrutura híbrida do campo da saúde pública (saberes e práticas), as características de sua produção teórica e a importância da categoria risco na informação de sua vertente intervencionista, fazem deste debate um exercício de encantamento e razão. O jogo de desconstrução da argumentação para atá-la em novos níveis de abstração, recuperando fios e diferenciando dimensões e significados, dão o sentido de pertinência de nossa prática ao mundo contemporâneo. É daí que estamos falando, da prática intelectual, de um campo sem limites setoriais e da possibilidade de teorização sobre os usos de linguagem de uma noção que operacionaliza em instâncias coletivas (como no caso da gestão ambiental) e individual (como no caso da incorporação de comportamentos saudáveis). Nesse sentido, podemos dizer que o texto de Mary Jane Spink, Trópicos dos Discursos sobre Risco: Risco-Aventura como Metáfora na ModernidadeTardia é, sem dúvida, um ensaio instigante.

Tendo por base a descrição dos sentidos históricos do conceito de risco, a autora procura demonstrar que "a noção de risco, entendida na perspectiva da linguagem em uso, permite explorar as mudanças que vêm ocorrendo nas formas de controle social", interpretadas como a transição da sociedade disciplinar (característica da modernidade clássica) para a sociedade de risco (identificada na modernidade tardia). Fundamentada nesse ponto de vista, a autora tece considerações sobre as atuais formas de destradicionalização do risco e define o seu termo argumento, o risco aventura, para "enfatizar um deslocamento importante dos sentidos modernos do risco que recuperam a aventura como dimensão positivada da gestão de riscos". Teoricamente é a noção de repertório interpretativo (Potter \&Wetherell, 1987) que fundamenta a análise das figuras de linguagem, que no texto explicitam os movimentos (síntese e reposicionamento) das mudanças de sentido observadas no uso de risco na linguagem, seja através de sua dimensão institucionalizada como discursos cristalizados, seja na perspectiva dinâmica do uso no contexto das práticas discursivas. Trata-se de uma forma específica de análise narrativa.

Uma transposição lógica do texto nos parece problemática. A imbricação nos usos de linguagem do risco (tomando por base de pesquisa os textos referidos pelo autora) com a análi- 
se. A historicidade do controle da incerteza em nível dos saberes, seja na forma da magia, religião ou ciência, aqui entendida em todo o seu conjunto de disciplinas, implica numa mediação entre a história de sua produção e o modo de produção em que eles se inscrevem. É necessário frisar que essa relativização metodológica não tem a ver com análises reducionistas, mas procura problematizar pelo menos duas questões de fundo: a metamorfose das relações sociais e a mudança da base produtiva industrial para a sociedade do conhecimento.

Como pontuado pela autora e discutido por Foucault (1977), o poder sobre a vida nas sociedades modernas se constitui em dois pólos interligados entre si por múltiplas redes de relações. O primeiro pólo se refere ao desvendamento e produção de discursos e práticas sobre o corpo humano, abordando-o enquanto máquina a ser otimizada, disciplinada em sua docilidade e produtividade. Esse pólo se organiza num conjunto de dispositivos disciplinares, que Foucault denomina anátomo-política do corpo. O segundo pólo, centrado em processos biológicos e sociais tais como reprodução, nascimento e morte, emerge de processos de controle aos quais Foucault denomina biopolítica das populações. É importante recuperar essas dimensões, uma vez que através delas o autor constrói a categoria dispositivo e o qualifica como disciplinar. Conforme discutido por Deleuze (1992), Foucault situou as sociedades disciplinares, contrapondo-as às sociedades de soberania, e sistematicamente sinalizou a brevidade daquele modelo.

Para Deleuze, as sociedades da modernidade tardia têm se transformado de sociedades disciplinares em sociedades de controle, em que o molde (veiculado pela fábrica, pela escola, pelo hospital) é substituído pela modulação. Em suas palavras: "uma mol dagem auto deformanteque mudasse a cada instante" (Deleuze, 1992:221) em que, por exemplo, a empresa (sem forma fixa, gás) substitui a fábrica (molde, corpo). O princípio modulador, diz o autor, se objetifica em controlatos (por exemplo o salário por mérito, a formação permanente) que, de forma complexa, se imbricam em geometria variável. Geometria esta imagética e virtual, como discutida por Virilio (1993). A vinculação discursiva risco e controle é inerente, mas se inscreve em esferas de análise diferentes, que só podem ser clarificadas tomando-se como base a sociedade do conhecimento, em que a informação é o produto principal de acumulação, modulador fundante dos processos de gestão da produção, hoje acontecimento sistêmico e simultâneo.
Ressaltamos, por fim, que as reflexões de Spink sobre as "novas modali dades de uso dos repertórios interpretativos sobre o risco" contribuem para o campo da saúde pública, na medida em que lançam luzes sobre as intervenções do controle de riscos, sejam eles como fatores de ordem individual ou coletiva, orientadas por escolhas racionais cuja lógica está informada pela economia material ou simbólica, centrada nas óticas do custo eficiência, ganho e perda etc. Cabe registrar que investigações no campo da saúde têm demonstrado que a percepção do risco de uma doença e a adoção de medidas preventivas não estão limitadas ao acesso a informações e à decisão individual; as mesmas decorrem de um processo dinâmico, construído a partir da experiência social e da visão de mundo dos sujeitos. Nessa perspectiva, estão conjugadas as representações das formas de vulnerabilidade à doença, assim como a percepção pessoal do risco e dos meios de controle do mesmo. As conexões entre a experiência social e as representações e práticas de risco (ou de proteção) devem ser entendidas à luz das mudanças nos sentidos de confiança e risco, promovidas pelas condições da modernidade (Giddens, 1991).

Pondera-se todavia, que algumas aproximações propostas no texto, por exemplo a transposição dos repertórios interpretativos acerca do risco, originários dos discursos sobre os indivíduos, para discursos referentes ao risco no plano coletivo são problemáticas. A utilização da análise narrativa é um instrumental pertinente à análise de discursos, entretanto, o texto em foco, no qual não são explicitados os exames parciais das fontes utilizadas, dificulta a lógica da argumentação. Nos parece assim, que a reflexão proposta necessita ampliar articulações entre categorias dos diferentes campos e saberes referidos, para que melhor subsidie a compreensão de representações e práticas em saúde coletiva.

DELEUZE, G., 1992. Conversações. Rio de Janeiro: Editora 34

FOU CAULT, M., 1977. A Vontade do Saber. Rio de Janeiro: Graal.

GIDDENS, A., 1991. As Conseqüências da Modernidade. São Paulo: Editora Unesp.

VIRILIO, P., 1993. O Espaço Crítico. Rio de Janeiro: Editora 34 
Silvana I nés Weller

Departamento de Medicina Preventiva e Social, Faculdade de Ciências Médicas, Universidade Estadual de Campinas, Campinas, Brasil. Silvana.Weller@connmed. com.ar
Mientras seguimos padeciendo los efectos avasalladores del "riesgo control", mientras seguimos buscando evidencias para poner de manifiesto el modo en el que se juegan los deseos en las conductas Ilamadas "riesgosas", Spink tiene la generosidad de al ertarnos sobre los nuevos ropajes que adopta el riesgo en la modernidad tardía. Así, la primera sensación que nos invade luego de la lectura del excel ente trabajo es la de que hemos sido burlados en "nuestras mejores intenciones"; el efecto de la ironía. Sin embargo, es difícil dejar de reconocer la vigencia de los conceptos desarrollados en el artículo en las noticias cotidianas, en los debates académicos sobre algunos tópicos, en las prácticas y representaciones de los usuarios y profesionales de los servicios de salud. Un primer punto para el debate es la propuesta de considerar - de hecho está colocado en el texto - la posibilidad de pensar este momento como una transición donde es posible encontrar los efectos de las dos modalidades; riesgo control y riesgo aventura. El fenómeno del autocuidado en salud puede ser pensado como una superficie que permite cristalizar situaciones que hacen de borde (y zona de pasaje) de los dos modelos (riesgo control, riesgo aventura).

Para el caso del sida, y utilizando el reconocimiento del otro como deseante (y no como sujeto de la norma) a modo de hilo conductor, podemos describir - simplificadamente - el siguiente movimiento ocurrido en los últimos catorce años: las primeras recomendaciones para evitar la transmisión del VIH iban en una dirección que parecía casi negar rasgos de humanidad a las personas afectadas, llegándose a proponer que un modo de evitar la transmisión era que las personas infectadas tuvieran relaciones entre ellas. Con el paso del tiempo, los aportes de las ciencias sociales y las ciencias de la subjetividad lograron modificar el escenario al poner de manifiesto que las dificultades de grandes grupos de poblaciones para lidiar con el preservativo estaban vinculadas a fenómenos culturales y subjetivos que hacían de obstáculo a los mandamientos normativos preventivos (v.g.: pérdida de la erección, deseos de fusión con el otro, existencia de relaciones de poder asimétricas en gran parte de las relaciones sexuales, etc.). Las personas no se "arriesgaban" a infectarse con el $\mathrm{VIH}$, les pasaban otras cosas. Sin embargo, y entrando en la fase de la ironía, encontramos hoy una proliferación de avisos clasificados en periódicos de gran tirada que promocionan de modo explícito oferta de servicios sexuales a mayor precio, sin uso del preservativo (Diario Clarín, Avisos Clasificados, Rubro 59, Argentina). Detengámonos en este espacio microsocial: hay dos personas unidas por una relación asimétrica (cliente, "prestador"), hay dos condiciones materiales de existencia (alguien quiere comprar, alguien necesita vender) y, por lo tanto, dos relaciones con el futuro. El cliente que paga tal vez podría ser ubicado como alguien en busca de aventura, aumento de adrenalina, sexo con riesgo para aumentar la excitación. Entiendo que el artículo de Spink nos brinda categorías para analizar la situación de la otra persona de nuestra escena, la persona (varón o mujer) que está cobrando más dinero por una relación donde se "arriesga" (o enfrenta el peligro!) a infectarse por el virus de la inmunodeficiencia humana $(\mathrm{VIH})$ a cambio de más dinero. ¿Son equiparables ambas situaciones? El nuevo discurso del riesgo es una nueva modalidad de encubrimiento de las inequidades sociales, ya que, al equiparar lo inequiparable, encubre las variaciones de opción de los diferentes grupos humanos.

El viaje del millonario Tito al espacio bien podría ser un ejemplo más de la fase de ironía del riesgo, con la consecuente idea de arriesgar la vida para que ésta tenga un sentido. Sin embargo, hay millones de personas que, lejos de subir a una nave espacial para experimentar el riesgo-aventura, están subiendo a un barco o a una balsa huyendo del peligro, de la muerte segura (por violencia política, por hambrunas, por falta de trabajo). Dependiendo de la inserción social de las personas, de su contexto histórico social, un grupo de gente sobre una balsa puede estar practicando turismo aventura y en ese sentido expresar el trópico de la ironía. Por el contrario, si ese grupo de gente (que tal vez esté en otra balsa, en el mismo mar) se encuentra huyendo de un país en guerra, la ligazón al riesgo aventura traería un quinto trópico del discurso, el oximorón, esto es la relación sintáctica de dos antónimos. A modo de ejemplos: "esta oscura claridad, que cae de las estrelIas"; "Ia música callada, la soledad sonora" (Ducrot \& Todorov, 1979:319).

Retomando entonces la visión panorámica de los sentidos históricos del riesgo, Spink marca que el paso del peligro, fatalidad al concepto de riesgo "emerge para falar da possibilidade de ocorrência de eventos futuros em um momento histórico em que o futuro passava a ser pensado como passível de controle" y que "as disposi ções sobre o futuro estão associadas às condi ções materiais de existência". Considerando las inequidades sociales a las que nos hemos referido, es preciso preguntarnos por las futuras derivaciones del interjuego del "riesgo- 
aventura" y la realidad material de millones de personas que hoy parecen vivir simplemente en peligro.

DUCROT, O. \& TODOROV, T., 1979. Diccionario Enciclopédico de las Ciencias del Lenguaje. México, DF: Siglo Veintiuno Editores.

Carlos Machado de Freitas

Centro de Estudos em Saúde do Trabalhador e Ecologia Humana, Escola Nacional de Saúde Pública, Fundação Oswaldo Cruz, Rio de Janeiro, Brasil. cmfreitas@ensp.fiocruz.br

\section{Diferentes atitudes frente ao risco e diferentes projetos de modernidade}

O debate sobre o termo risco e seus discursos na modernidade são um tema atual e de grande importância para o campo da Saúde Pública, pois sempre nos remete à possibilidade de debatermos diferentes projetos de sociedade e de modernidade.

O termo risco surge com o próprio processo de constituição das sociedades contemporâneas a partir do final do Renascimento, quando ocorreram intensas transformações sociais e culturais associadas ao forte impulso nas ciências e nas técnicas, às grandes navegações e à ampliação e fortalecimento do poder político e econômico de uma nascente burguesia (Freitas, 1997). Constitui-se em uma das formas de expressão de um projeto de organização social, política, econômica e cultural que, tendo suas origens na nascente burguesia da Europa Ocidental, foi cada vez mais se estendendo sobre todo o planeta e se intensificando nas sociedades que atingiu. Neste projeto, o homem, através de ações racionais que objetivam ordenar o mundo em que vive, deve determinar seu próprio futuro, transformando-o em um território a ser conquistado ou colonizado e que Ihe possibilitará al cançar a liberdade, a felicidade ou a satisfação das suas necessidades (Giddens, 2000; Toraine, 1994).

Neste processo histórico dois fundamentos moldaram o termo risco e suas aplicações na modernidade, sendo estes: a perspectiva utilitarista e a concepção elitista de democracia.

Para a perspectiva utilitarista, as ações racionais dos indivíduos deveriam ser orientadas para determinados fins com o objetivo de alcançar os melhores resultados; felicidade, utilidade, satisfação, entre outros, sendo o mercado o protótipo do processo que liga as preferências individuais às escolhas sociais e sua legitimação. Orienta a luta pela própria sobrevi- vência e a busca para a prosperidade em um mundo dominado por aparente caos e incertezas, permitindo substituí-lo por outro, dominado pela ordem e a previsibilidade (Freitas, 1997).

A concepção elitista de democracia se encontra na base do que Giddens (1990) denomina de sistemas abstratos de confiança, que envolvem as instituições da modernidade que organizam os principais aspectos de nossa vida cotidiana e que se encontram vinculadas às questões decisivas relativas à segurança, risco e perigo no mundo moderno. Para a concepção elitista de democracia, a preocupação maior é manter a estabilidade de um sistema social baseado no utilitarismo. A limitação da participação dos cidadãos nos processos decisórios não é apenas aceita, mas também justificada como sinal de fé e lealdade para com o sistema e suas elites técnicas e políticas, essas sim, capazes de realizar os melhores julgamentos para a maximização de ganhos para todos (Freitas, 1997).

Na modernidade tardia, assistimos ao triunfo do projeto de uma sociedade industrial e capitalista, em que as preferências individuais e escolhas sociais reproduzem, em maior ou menor grau, uma ordem instrumentalmente racional que tem como referência o mercado. Entretanto, falhou a perspectiva de que a expansão e intensificação da intenção de controle de riscos modernidade, como modo de regular, normatizar e submeter o futuro ao nosso domínio, representaria para muitos a liberdade, a felicidade ou a satisfação de suas necessidades. Hoje, somos todos forçados a reconhecer a imprevisibilidade das ameaças provocadas pelo desenvolvimento técnico-industrial e a procurar modos diferentes de relação com a incerte$z a$, tornando-se obscurecido o horizonte de um mundo e um futuro controlados pela razão instrumental (Beck, 1997; Giddens, 2000).

Neste contexto atual, conforme observa Beck (1997), alguém que considere o mundo como um risco irá se tornar incapaz de agir, de modo que vem se produzindo o oposto, sendo o risco-aventura apenas uma das diversas atitudes constituídas para enfrentar a imprevisibilidade dos riscos modernos. Thompson \& Wildavsky (1983), por exemplo, na perspectiva de uma teoria cultural dos riscos, identificam cinco atitudes, tais como: indi víduos atomizados (a vida é uma loteria, os riscos estão fora de controle e a segurança é uma questão de sorte), burocratas (riscos são aceitáveis enquanto as instituições têm rotinas para controlá-los), eremitas (riscos são aceitáveis enquanto não envolvem a coerção de outros), igualitários (riscos deveriam ser evitados a menos que sejam 
inevitáveis para proteger o bem público) e empreendedores (riscos oferecem oportunidades e devem ser aceitos em troca de benefícios). Estas diferentes atitudes, como observam os autores, manifestam que as escol has dos riscos e de como viver, são tomadas conjuntamente, já que a seleção das formas de organização social predispõe as pessoas a selecionarem determinados riscos em detrimento de outros e de outras formas de organização social. Também manifestam as contradições de um projeto de modernidade para o qual as ações racionais que buscam ordenar o mundo, deveriam ter como fundamentos somente a perspectiva utilitarista e uma concepção el itista de democracia.

O que se encontra por trás das atitudes e discursos sobre o risco e dos debates que the acompanham na modernidade são diferentes projetos de sociedade. Dentre esses projetos podemos considerar que o risco-aventura simboliza aquilo que Giddens (1990) denomina de radicalização do projeto da modernidade. $\mathrm{Na}$ sua forma mais ambiciosa, aprofunda o individualismo e afirma que o homem é o que ele faz, reduzindo a sociedade e nossas vidas a uma empresa lutando para sobreviver num mercado internacional. Os poderes ocultados passam cada vez mais a ser definidos em termos de gestão e de estratégia, que individualizadas e restritos ao espaço privado, deixam, como observa Torraine (1994), apenas um abismo sem fundo lá onde havia o espaço público, social e político. Trazer para o debate outras atitudes e discursos sobre os riscos na modernidade, que envolvem outros projetos de sociedade, como os que orientam as críticas dos jovens, partidos de esquerda e organizações nãogovernamentais ao processo de globalização em curso e seus riscos para a saúde e o meio ambiente é, então, de vital importância. Spink perde essa oportunidade, ao limitar sua abordagem a apenas uma perspectiva do risco.

BECK, U., 1997. A reinvenção da política: Ruma a uma teoria da modernização reflexiva. In: Modernização Reflexiva - Política, Tradição e Estética na Ordem Social Moderna (U. Beck, A. Giddens \& E. Lash, org.), pp. 11-71, São Paulo: Editora Unesp.

FREITAS, C. M. \& GOMEZ, C. M., 1997. Análise de riscos tecnológicos na perspectiva das Ciências Sociais. História, Ciências, Saúde-Manguinhos, 3:485-504.

GIDDENS, A., 1990. As Conseqüências da Modernidade. São Paulo: Editora Unesp.

GIDDENS, A., 2000. Mundo em Descontrole- O Quea Globalização está Fazendo de Nós? Rio de Janeiro: Editora Record.

THOM PSON, M. \& WILDAVSKY, A., 1983. A proposal to create a cultural theory of risk. In: The Risk Analysis Controversy - An Institutional Perspec-

tive (H. C. Kunreuther \& E. V. Ley, ed.), pp. 145161, Berlin: Springer-Verlag.

TOURAINE, A., 1994. Crítica da Modernidade. Rio de Janeiro: Editora Vozes.

Rita Barradas Barata

Santa Casa de

Misericórida

São Paulo, Brasil

ch.medsoc@santacasasp. org.br
O artigo em questão apresenta uma diversidade muito grande de planos de análise tornando relativamente temerária a tarefa de debatê-lo. Para não incorrer então nas inúmeras "armadiIhas" apresentadas pela autora, optei por colocar-me estritamente da perspectiva de um praticante da Epidemiologia, campo no qual o conceito de risco desempenha papel nuclear.

O conceito de risco, estrito senso, em qualquer campo de saber científico ou tecnológico em que venha a ser utilizado, tem um único e preciso significado: probabilidade de ocorrência de um evento de interesse. Entretanto, quando se trata de olhar, como faz a autora, para a linguagem em uso ou para os usos da linguagem em diferentes domínios do saber, aí incluído o plano do cotidiano, ocorre uma verdadeira "explosão polissêmica" que esvazia o conteúdo estritamente conceitual da palavra risco, dando lugar a uma noção multifacetada, carregada de valor.

Mantendo-se fiel ao conceito de risco, não haveria como atribuir-lhe conotações negativas ou positivas, visto que o cálculo da probabilidade de ocorrência de um evento é em si mesmo, um procedimento neutro. Todavia, as atribuições de sentido operadas no interior das práxis discursivas conferem à noção de risco ora sentidos positivos, como alguns daqueles pontuados pela autora ao apresentar a idéia de risco-aventura, ora sentidos negativos, como ocorre mais freqüentemente no interior do discurso epidemiológico e na prática em Saúde Pública.

Os variados usos que a palavra risco tem, principalmente no cotidiano, correspondem freqüentemente a um processo de reificação do conceito levando à confusão entre a possibilidade de ocorrência de um evento e as circunstâncias ou elementos "responsáveis" por essa ocorrência. Este efeito pode ser verificado no próprio texto aqui analisado quando a autora se refere ao fato de que na etapa pré-capitalistas "esses eventos (terremotos, furacões e outras desgraças) não eram denominados riscos. Eram referidos como perigos, fatal idades, hazards...". Aqui, a primeira armadilha nesse 
terreno pantanoso da discussão do risco. A confusão muito comum entre o processo - possibilidade de ocorrência - e suas possíveis "causas".

Ao se passar do campo conceitual para os usos de linguagem, ocorrem inúmeros deslizamentos e, talvez, a mudança mais expressiva se faça justamente na incorporação de um valor negativo à idéia de risco. Na Saúde Pública e na Epidemiologia, as medidas de risco remetem a probabilidades absolutas ou relativas de ocorrência de doença, morte ou outras situações deletérias para a saúde, sendo portanto, quase que automática a vinculação entre a noção de risco e a idéia de agravos negativos. Esta, uma segunda armadilha armada entre a formulação e a utilização do conceito, cujas implicações e efeitos nem sempre estão claramente evidenciados.

As três áreas identificadas pela autora no campo da análise de riscos têm seus equivalentes na Epidemiologia e na Saúde Coletiva. O cálculo dos riscos, a percepção do risco pelo público e a gestão deles podem ser vistos como etapas da produção, divulgação e aplicação de conhecimentos epidemiológicos no que tange ao processo saúde-doença em coletividades. Assim, é parte das tarefas da epidemiologia enquanto disciplina científica, efetuar o cálculo de risco para a ocorrência de doenças e agravos à saúde de populações ou de suas frações em determinadas situações ou contextos. Uma vez produzidos, esses conhecimentos destinamse, em parte, a provocar mudanças de comportamento entre as pessoas e para isso devem ser divulgados ao público em geral e incorporados a suas práticas cotidianas, do mesmo modo que, destinam-se a informar a prática dos profissionais de saúde. Finalmente, as propostas de políticas e programas voltados para a proteção e recuperação da saúde podem ser vistas como ações no âmbito da gestão de riscos.

Assim sendo, a análise de riscos deveria ser avaliada, mais propriamente, como um instrumento ou uma tecnologia (no sentido amplo do termo tecnologia) potencialmente aplicável a distintos âmbitos da vida, não se constituindo em um campo interdisciplinar mas podendo ser aplicada a diferentes ordens de problemas.

Talvez as perguntas centrais sejam porque e como a noção de risco chegou a ser dominante na modernidade tardia? Que necessidades concretas estão sendo atendidas através da análise de riscos? Que características tem essa episteme na qual a noção de risco adquire tamanha importância?

Não seria preferível adotar a designação de Foucault, diferenciando um período "clássico" antecedendo a modernidade propriamente di- ta, para demarcar as diferenças entre os sécuIos XVIII e XIX, entendendo a contemporaneidade como um aprofundamento das características da modernidade?

Ao determinismo mecânico do século XVII, o período das Luzes veio acrescentar a fé cega na razão. A incerteza é vista aí apenas como um sinal da precariedade dos conhecimentos já alcançados pelas ciências naturais. A crença na Razão pressupõem que, mais dia menos dia, as leis de funcionamento da natureza e da sociedade serão conhecidas e portanto, poderão ser aplicadas para "domesticar" o futuro. O modernismo no entanto porá por terra essa crença. A velocidade e a instabilidade serão suas marcas. "Tudo o queé sólido desmancha no ar" como muito bem enfatizou Marx, no Manifesto Comunista.

O conceito de risco, assim como o grande desenvolvimento da estatística, principalmente da teoria das probabilidades, provavelmente aparecem como formas de lidar com a indefinição nas quais a imprevisibilidade é substituída pelo cálculo de graus de incerteza.

A equação em jogo não parece ser fundamentalmente a de oposição entre solidariedade e eqüidade versus iniqüidade e egoísmo, mas antes, a oposição entre previsível e imprevisível.

Outra aspecto que poderia ser considerado na análise da posição proeminente da noção de risco na modernidade, diz respeito à operação de redução de todas as qualidades dos objetos a apenas uma: a quantidade. O fetiche do número, que em parte, decorre de seu caráter objetivo, neutro, não controverso, marca de maneira importante a modernidade e, sem dúvida, contribui para a relevância conferida à noção de risco.

A passagem da sociedade disciplinar para a sociedade de riscos merece um olhar mais detido. Os dois pólos podem estar nitidamente delineados, entretanto, a transformação ou ruptura de um momento a outro não está suficientemente elucidada. Como, quando e porque a disciplina deixa de ser a forma efetiva de administração do futuro, cedendo espaço à gestão de riscos?

Embora o projeto da autora fosse analisar o emprego da noção de risco no contexto da teoria dos jogos, da economia, da saúde e da biotecnologia o que se viu no presente texto foi a análise do uso cotidiano da noção de risco tal qual ela aparece na mídia impressa aplicandose ora a um, ora a outro desses conteúdos.

A rigor a autora não faz a análise do uso da noção de risco em diferentes domínios do saber. A análise volta-se exclusivamente para o 
uso cotidiano, ou seja, tenta flagrar a prática discursiva em ação para fora do universo de elaboração e validação interna dos distintos campos de saber onde a noção pudesse vir a ter utilidade. Este é um ângulo de análise profundamente interessante na medida em que todos os saberes humanos almejam, imediata ou mediatamente, pelo retorno à imediatez, ou seja, pela incorporação no fazer e pensar da cotidianeidade, critério último de validação externa de sua pertinência.

Outro mérito da análise é chamar a atenção para as possíveis conotações positivas da noção de risco, pelo menos em uma das suas inúmeras formas, aqui denominada de riscoaventura. Sem pretender azedar ou entornar o caldo, poderíamos lembrar que mesmo algumas dessas conotações poderiam ser contaminadas, irremediavelmente, pelos valores negativos que a noção carrega habitual mente. Um dos exemplos utilizados pela autora, as formas de edificação, uma das formas culturais do risco-aventura, admitem quase que imediatamente, para os olhos viciados de um sanitarista, enxergar os inúmeros riscos ou probabilidades de ocorrência, de efeitos danosos à saúde tais como acidentes mais ou menos graves e exposição a inúmeros agentes de doenças. Apenas para ficar em um exemplo atual, a epidemia de febre amarela, vivenciada recentemente, esteve bastante relacionada com a expansão do chamado turismo ecológico.

A complexidade e os aspectos contraditórios inerentes à delimitação e cálculo dos riscos, repercutem fortemente nas formas de percepção deles pela população e também nas possíveis propostas de gestão dos riscos, seja pela comunidade de especialistas ou pelos próprios indivíduos. Talvez esse seja um dos principais motivos do mal estar de nossa civilização.
Maria Lúcia da Silveira

Departamento de Saúde Comunitária, Universidade Federal do Paraná, Curitiba, Brasil marial@onda.com.br
Uma das grandes perplexidades vividas na atualidade pelos trabalhadores de saúde é o paradoxo proporcionado pela situação na qual, por um lado, constata-se que inúmeras fontes alimentam um caudal de informações e orientações para a vida mais saudável e incitam o exercício da autonomia e da responsabilidade pessoal sobre a saúde e, por outro, que há uma distância aparentemente intransponível entre o saber e o fazer, de tal forma que aquele que sabe (ou que conhece o risco) nem sempre faz o certo (evitar) para si e para os outros; ao contrário, deliberadamente se expõe, expondo outros ainda, a comportamentos malsãos.

Ao enfrentar este limite das ações educativas e para não cair no niilismo paralisante, cumpre enfrentar o desafio de compreender o que o provoca. Situa-se justamente aqui, a grande contribuição de Spink. Se ainda não nos traz uma proposta de ação, ela permite avançar na compreensão dos motivos que determinam tais comportamentos.

Indicando explicitamente no próprio título, ter assumido a dimensão histórico-social (que evidentemente inclui a psicológica e cultural como componentes do processo saúde e doença), ela caracteriza o risco como "aventura”, localizando esse tipo particular no contexto sócio-histórico da modernidade tardia, remetendo-nos, por essa via, a assunção de desejos e prazeres como mediadores necessariamente presentes. Aqui, no meu entender, se encontra a sua maior contribuição, que refere-se diretamente ao campo da subjetividade, amplamente escamoteado das práticas sanitárias até hoje, em que pesem os inúmeros discursos contrários.

Assim, ao invés de isolar essa característica contida no conceito de risco, ela prefere liga-lo aos outros elementos contemporâneos que definem o contexto particular, no qual ele pode ser entrevisto e ao qual se aplica de forma peculiar. Transcende, portanto, o espaço psicológico ao qual, no primeiro momento, pareceria restrita, e localiza-o em pleno campo social, numa abordagem que parece muito adequada para se entender o que se passa hoje com o dito "comportamento de risco".

A autora trabalha o risco na perspectiva da linguagem e eu passo da linguagem ao cotidiano, pois como ela própria deixa claro, a linguagem nada mais é do que a sua expressão.

Agir de forma arriscada, pela "adrenalina" simplesmente, parece de fato, ser a tônica atual. É o que acontece entre os jovens, que no seu dia-a-dia expõe-se constantemente e em ações 
aparentemente incompreensíveis. Isto é evidente em qual quer situação e não apenas naquelas que dizem respeito diretamente à saúde. Certos reclamos de professores parecem trazer implícito o conceito defendido por Spink, assim como a mesma perplexidade da qual eu falava no início: “Eu sei que égostoso ficar num papinho com os colegas, azarar as gatinhas como eles dizem, mas o que não consigo entender é que ficam na rua, no meio do maior movimento de carros... Parece que el es gostam de ficar ali se arriscando, parece que se divertem com o perigo!".

"Os alunos adoram ir à livraria X. O gerente vol ta e meia vem reclamar que eles entram lá para roubar. Eu sei que eles não precisam fazer isso, pois de maneira geral, todos têm o que precisam ea gente dá um jeito de arranjar o necessário para os que não podem comprar. Não sei o que faz com que eles tenham prazer em praticar pequenos furtos: uma borracha, um bloquinho, um lápis... A turma fica na rua esperando, enquanto um entra lá, dá uma disfarçada, surrupia qualquer coisa e sai, sendo recebido em triunfo, parece mesmo que para eles é um grande desafio, pois disputam a vez de ir atélivraria e voltar mostrando o seu troféu para a galera...! Não sabemos mais o que fazer!" (orientadora educacional em reunião de pais de alunos de uma escola pública da região central de Curitiba).

O comentário de uma médica-educadora a propósito de outro tema, contribui, à sua maneira, para reforçar essa impressão: “O proble ma da educação sexual é que fica tudo muito bem explicadinho, mas ninguém diz o que fazer com o tesão, e para dar conta do tesão é preciso se arriscar dealguma forma".

Assim, a Epidemiologia confronta-se com a necessidade de pensar em quantas situações o sabor, o prazer de se arriscar, a aventura enfim, predomina, e o quanto esse predomínio esconde o risco, reduz a sua importância, a sua prioridade, fazendo com que pessoas se exponham para não comprometer a aventura do prazer. Tal acontece, por exemplo, no ato arriscado de transar sem proteção. Aqui a incerteza, embora conhecida, não é obscurecida, é simplesmente olvidada em favor do ato prazeroso que poderia se perder ante a ameaça de uma camisinha, por exemplo.

O mesmo se aplicaria à necessidade não atendida de diminuir a velocidade do carro ou de outro gesto qualquer de prevenção, nas mais variadas situações que impliquem em algum tipo de ameaça. Nesse caso, o certo, que é o prazer, não é trocado pelo incerto (o risco, a probabilidade: posso ou não pegar uma doença, me acidentar ou ter prejuízos materiais) e mais: a ânsia de garantir o prazer pessoal omite a probabilidade do risco do outro ou atrai o outro para as situações-limite do arriscar-se na aventura, por exemplo, de um "racha" urbano ou de uma roda de tóxicos, entre tantas outras possibilidades.

Mas não é só isso, outras ponderações muito interessantes são trazidas por Spink, tal como a possibilidade associada. Coerente com a autora, o dito popular: "quem não se arrisca, não petisca", afirma que há no arriscar-se, a possibilidade associada (ainda que a probabilidade possa ser desfavorável) de ganho, a promessa de recompensa final, e a aventura faz uma referência explícita a ela, o que, justamente, Ihe confere um gosto irresistível. Isto permite compreender tanto o jogador contumaz, o rapazinho ou o adulto bem informado que se Iança numa aventura sexual, o investidor na bolsa... E muitos outros aventureiros do risco. Sem dúvida, o conceito que nos apresenta é passível de generalização na aplicação, o que constitui outro mérito da autora, permitindo que possamos fazer um juízo mais abrangente dos comportamentos assumidos pelas pessoas nessa modernidade tardia e venturosamente perigosa!

Se no Histórico ela aponta que a noção de risco implica em se ter uma noção de futuro, o que fazer hoje diante daqueles aos quais "o futuro a Deus pertence?" Como enfrentar o risco se seus valores positivos são confrontados com esse contexto? Se só se pode saber do presente, se o futuro, além de imprevisível, não é de nosso domínio, que táticas poderão funcionar preventivamente?

A idéia do risco-aventura nos permite também compreender aqueles que nada têm a perder, ou têm tão pouco que o sabor de um ou outro risco compensa mais do que a monotonia da carência cotidiana: presidiários, mendigos, milhões de pobres... Para quem simplesmente sobreviver já é uma dolorosa aventura, já é a prova de vencer o desafio de manter o sopro vital em meio à carência quase absoluta, o que prevenir? O que deixar de fruir num universo tão pouco prazeroso, onde alimentar-se, dormir, comer, transar, tudo é risco, mas tudo é aventura de manter a vida mesmo que por breves instantes? Mesmo que pelo breve tempo, suficiente apenas para acalentar um sonho irrealizável talvez e encontrar algo que o mantenha por mais um pouco, e assim sucessivamente, vivendo aos empurrões, sobrevivendo de migalhas de prazer?

Seguindo por aqui e considerando o paralelo entre capitalismo e cálculo do risco, apon- 
tado por Bordieu (Bourdieu, 1979), esta não seria uma via para explicar a crescente pauperização da epidemia de AIDS (e de outras tantas)? Pois aqueles situados à margem dos ganhos e das benesses do capital não se prenderiam a outra lógica, na qual o futuro objetivo, quantificável em termos daquilo que vai se conseguir ganhar, previsível portanto, não estaria excluído para eles? Sobrando apenas essa rude aventura, quase inexoravelmente mortal ou quem sabe mais precocemente mortal para eles?

E ainda, "gestão positivada da gestão de riscos" não é exatamente isso? A metamorfose da ameaça para a aventura e seu gozo, mesmo que fugaz e seguido talvez de tragédia (é o que o profissional de saúde antevê) ou de da glória de sair ileso (antevista e desejada por aquele que se arrisca, se aventura). Não será apenas este anseio, este sonho - ainda que não explicitado - que move o sujeito e que anularia as freqüentemente enfadonhas ações educativas em saúde? A proposição da autora é um desafio à reflexão eà mudança das mesmas.

Outro ponto por ela levantado com o risco-aventura: a da sua utilidade nestes tempos; enfrentaríamos o cotidiano perigoso da sociedade capitalista urbana se não vivêssemos com a tranqüilidade possibilitada pelo risco aventura na sua função edificadora? Mesmo no enfrentamento das suas formas corrompidas?

Como fica a atuação em saúde se as formas corrompidas de risco-aventura se desenvolverem justamente para, de certa forma, proteger os excluídos sociais? Pois se a exclusão social (vida de rua, tráfico, etc.) pressupõe sujeitos que aceitam ou aos quais é imposta pelo sistema social, o risco aventura em suas formas mais corrompidas e estas, por sua vez, impõem riscos a outros membros da sociedade que, estariam adaptados por já terem assimilado outras formas de risco e sua função edificadora?

Cabe aqui lembrar que o próprio texto mostra que a passagem da sociedade disciplinar para a de risco, significou assumir a transgressão na sua dimensão prazerosa, naquela que significa libertação, ignorando ou enfrentando o que esse processo tem de ameaçador. E, nesse cenário, confrontar o risco-aventura e seus propósitos dionisíacos, com os de polícia que os serviços de saúde mantêm: assegurar a ordem, canalizar o crescimento da riqueza e manter as condições de saúde (Foucault, 1997).

Finalmente, outro aspecto a destacar é o reconhecimento do caráter sistêmico do risco e a conseqüente necessidade de romper as barreiras disciplinares, departamentais e até mesmo nacionais para o seu enfrentamento.

BOURDIEU, P., 1979. O Desencantamento do Mundo. São Paulo: Perspectiva.

FOU CAULT, M., 1977. A Vontade de Saber. Rio de Janeiro: Graal.

\section{Sandra Caponi La aceptabilidad del riesgo}

Departamento de Saúde Pública, Centro de Ciências da Saúde, Universidade Federal de Santa Catarina, Florianópolis, Brasil. caponi@cfh.ufsc.br
El trabajo de Mary Jane Spink presenta una propuesta de análisis del concepto de riesgo instigante y novedosa. Nos detendremos aquí en la transición, analizada por la autora, de una sociedad disciplinar para una "sociedad del riesgo": mientras que la primera sería la forma característica de la modernidad clásica, la segunda indicaría una forma emergente de la modernidad tardía. Las preocupaciones típicas de la sociedad disciplinar con la prevención y la norma como mecanismo de control del riesgo parecen desplazarse a favor de una sociedad donde el riesgo ya no es vivido como una amenaza a ser controlada, cuantificada y sometida a estrategias de prevención, sino que es pensado en términos de aventura, de margen de novedad, en fin, de imponderabilidad. Nos habla así del riego-aventura que se traduce en deportes, en maniobras económicas que suponen "ganarlo o perderlo todo", o en los Ilamados modos ilegales de riesgo.

Proponemos leer este texto como punto de partida para volver a examinar, una vez más, el modo como la salud pública ha pensado ese concepto. Podemos decir que, desde los estudios deVillermé sobre las condiciones de vida de los obreros dealgodón, hasta el últi mo estudio epidemiológico sobre violencia en el tránsito, una misma estrategia semantiene: presentar, con el auxilio demodel os estadísti cos cada vez más sofisticados, los riesgos detectados y el modo de prevenirlos y gestionarlos. Pero, hay algo que, desde 1846 hasta nuestros días, parece quedar necesariamente excluido de esos estudios. Ese espacio de riesgo que no lleva necesariamentela marca de lo indeseado, aquell o que parece ser casi deliberadamente procurado, como si se imaginara que allí donde las estadísticas muestran lo negativo a ser controlado se ocultara cierta positividad, menos evidente. Así, en 1846, Villerméargumentaba contra los riegos de pauperización, inmoralidad y pereza que representaba el consumo dealcohol para los trabajadores del algodón. Sin embargo, los operarios a 
quienes se refería ese estudio podían encontrar allí un espacio defuga, deauto-reconocimiento, de camaradería, en fin, de placer. Ese mismo razonamiento puede ser repetido en relación a diferentes estudi os que se detienen en el cál culo y en la gestión de ri esgos, esto es, en la identificación delos efectos adversos potenciales del fenómeno en análisis, y en los modos de evitarlos. El texto de Mary Spink nos permite imaginar aquello que estos estudi os pueden haber dejado entre paréntesis: la dimensión de aventura que puedeestar asociada al riesgo.

Nos preguntamos de que manera podríamos utilizar la idea de riesgo-aventura para pensar el concepto de salud, excluyendo los temores y los fantasmas que clásicamente han estado asociados a los conceptos de "grupo de riego" o de "comportamiento de riesgo". Creemos que el concepto de salud esbozado, en año 1946, por Georges Canguilhem nos permite una aproximación privilegiada para el análisis del riesgo como positividad. La salud era comprendida, entonces, en términos de "apertura al riesgo". "Al contrario de ciertos médi cos siempre dispuestos a considerar a las enfermedades como crímenes, porque los interesados son de cierta forma responsables, por exceso o por omisión, creemos que el poder y la tentación de tornarse enfermo es una característica esencial de la fisiología humana. Transponiendo una frase deValery se puede decir que la posibilidad de abusar de la salud forma parte de la salud" (Canguilhem, 1998:133). No existe aquí espacio para las Ilamadas "conductas de riesgo", ni para los así llamados "grupos de riesgo", ambos asociados con ideas de abuso y exceso, o simplemente con irresponsabilidad y descuido.

Salud es entonces poseer una capacidad de tolerancia o de seguridad que es más que adaptativa. Es la capacidad de asumir riesgos y de poder superarlos. Si consideramos la aceptabilidad que los medios de comunicación parecen haber acordado a ciertos tipos de riesgos considerados "legítimos" y, más aún, dignos de encomio, como los deportes de riesgo, o las conductas empresariales marcadas por la adrenalina y la emoción, parece que la modernidad tardía vendría a confirmar esa idea de definir la salud por la posibilidad de superar las capacidades iniciales.

Pero es aquí que aparecen las dificultades y las diferencias en relación al texto de Mary Spink. Si su mérito está en saber señalar y denunciar la existencia de una percepción positiva del riesgo, creemos que su dificultad está en la falta de diferenciación entre riesgos legítimos o socialmente deseables (deportes, desafíos económicos, etc) y esos otros tipos de riesgo que históricamente la salud pública consi- deró y continúa considerando como no aceptables. Es verdad que esos modos de acción hiper-valorizados por nuestra sociedad parecen traducir cierta necesidad de asumir que el riesgo hace parte de nuestras vidas, pero existen riesgos moral y socialmente tolerados y otros a los cuales la autora (aún considerándolos dentro del mismo espacio de riesgo-aventura) les reserva el nombre (propuesto por Caillois) de "formas corrompi das de juego". Esta falta de diferenciación entre dos niveles de riesgo, los médicamente correctos (que pueden aparecer como tapa de revista) y los médicamente no tolerables, no puede ser considerada secundaria.

Si es verdad que existe una omnipresencia del riesgo-aventura en la sociedad contemporánea, entonces es necesario explorar la distinción, que la autora simplemente enuncia, entre aquellos autores que consideran que las formas socialmente aceptadas de riesgo-aventura (deportes de riesgo) no son más que una extensión de la sociedad disciplinar y aquellos autores que se detienen a analizar el papel social que ocupan las, así llamadas, formas corrompidas de riesgo. Es que el riesgo como estrategia disciplinar de producción de una humanidad físicamente y económicamente maximizada (aunque políticamente minimizada) suele definirse por su oposición a formas consideradas ilícitas y médicamente peligrosas de riesgo, aquellas rápidamente asociadas a la producción de una humanidad económica y físicamente "minimizada". Es entonces que la hipótesis de la transición entre dos modos de sociedad (de la norma y del riesgo) parece perder su fuerza, y la seducción del riesgo como aventura y positividad parece limitarse a los riesgos médicamente correctos.

Aún así, es necesario reconocer que la omnipresencia del riesgo y sus metáforas en la modernidad tardía parece posibilitarnos un nuevo modo de enfrentar los desafíos de la salud pública, como lo demuestran las estrategias de prevención del Sida. Tal pareceque es allí, más que en las i deas de riesgo aventura vehiculizadas por la práctica deciertos deportes, dondeun nuevo modo detematizar el riesgo parece poder descubrirse. Ya no se puedehablar de conductas o grupos de riesgo, y las prácticas preventivasestimuladas, tal es como el uso de preservativo o los programas de reducción de daños para usuarios de drogas inyectables, parecen hablar de una nueva aceptabilidad del riesgo. Allí, la distinción entre riesgos médicamente aceptables y formas corrompidas de riesgo parece, poco a poco, comenzar a desaparecer.

CANGUILHEM, G., 1998. Le Normal et le Pathologique. Paris: P.U.F. 
Dora Lucia de Oliveira

Departamento de Enfermagem MaternoInfantil, Escola de Enfermagem, Universidade Federal do Rio Grande do Sul, Porto Alegre, Brasil. dora@enf.ufrgs.br
O artigo de Spink enfoca um tema praticamente impensável no campo da saúde pública - o de um certo sentido positivo para risco. Interpretado desde um ponto de vista preventivista e individual ista, "risco" é predominantemente visto pela saúde pública como resultado de escolhas equivocadas de estilos de vida, salvo quando o risco em questão tem relação com fenômenos naturais. Tendo incorporado significados eminentemente negativos (mesmo quando usado no sentido de aventura), "risco à saúde" tem a ver com culpa, irresponsabilidade, incompetência e ignorância. Um exemplo clássico é a abordagem sanitarista do "problema" da adolescência. Teses sobre o comportamento de risco dos adolescentes, têm sido embasadas numa perspectiva essencialista, que propõe como "natural" o espírito aventureiro de "todos" os adolescentes. Considerado como negativo, porque põe em risco a integridade física do indivíduo, esse ímpeto dos adolescentes pela aventura é entendido como associado a outras características "naturais" da adolescência, tais como imaturidade e senso de invulnerabilidade. Isso tem rendido aos adolescentes um lugar de destaque nos discursos e ações preventivas da nova saúde pública. A solução apontada para o problema tem sido promover a "correção" (via informação) das percepções e atitudes "equivocadas" dos adolescentes frente a situações de risco, com o intuito imediato de modificar seus comportamentos e de torná-los competentes no "cuidado de si". Dado que comportamentos e percepções de risco são "sociais" e "culturais", além de individuais, muitas dessas ações acabam frustradas, como é o caso das ações de prevenção da AIDS. É interessante essa ênfase da saúde pública na negatividade do risco, apesar de clara a sua base ideológica neo-liberal, a qual em outros campos admite a positividade do risco. Em Free to Choose, Friedman \& Friedman (1980) argumentam que correr risco é bom e que a tendência de tomar decisões arriscadas é uma característica positiva de sujeitos empreendedores. Nessa perspectiva, aqueles que estão dispostos a correr riscos adquirem o direito de recolher os benefícios que possam advir de decisões arriscadas, tais como aumento de renda e melhor nível de saúde e educação. Este parece ser um forte argumento na modernidade tardia, na medida em que mesmo os teóricos da igualdade social, como Philips (1999), para os quais privilégios resultantes de desigual dades herdadas são imorais, tendem a aceitar privilégios que resultem de escolhas arriscadas. Volto ao argumento de
Spink sobre a emergência do risco-aventura como metáfora da modernidade tardia, com o qual concordo. E há muitos outros sentidos modernos de risco a descobrir e explorar. É o caso de risco como metáfora de autonomia, uma maneira de apresentar o self como em controle de si numa sociedade na qual o risco é onipresente, e o "cuidado de si" não significa mais optar por escolhas seguras, mas escolher que riscos correr. Esta concepção de risco como auto-governo ficou claramente evidenciada nas falas das adolescentes que entrevistei em uma pesquisa sobre "formas de ver" os riscos do sexo, recentemente concluída (Oliveira, 2001). O problema é que teses sobre a diversidade semântica, sobre lógicas e racionalidades do risco, como a minha própria, a defendida no artigo de Spink, a de Giddens (1996), de Beck (1992) ou mais especificamente, na área da saúde, a de Petersen \& Lupton (1996), ainda são estranhas aos paradigmas da saúde pública. No campo da saúde "risco" tem um significado monolítico, podendo variar limitadamente conforme os experts que o define. Definições epidemiológicas de risco têm produzido discursos do tipo "risco é...", deixando pouco espaço para concepções de risco que utilizem outros parâmetros. Nessa perspectiva o conteúdo cultural das concepções de risco dos indivíduos é desvalorizado e tido como algo que influencia interpretações subjetivas (e por isso potencialmente equivocadas) sobre o que a ciência define como verdade sobre risco. Como no uso de risco no sentido de aventura, o entendimento de risco como auto-governo é evidência de que na modernidade tardia há novos sentidos para ele, produzidos em resposta ao que Spink chama de "imponderabilidade e volatilidade dos riscos manufaturados". O reconhecimento da existência de diferentes sentidos para risco seria um bom começo para a necessária revisão da concepção sanitarista de risco, a qual, com raras exceções, tem sido arrogantemente proposta como verdade.

FRIEDMAN, M. \& FRIEDMAN, R., 1980. Freeto Choose London: Secker \& Warburg.

BECK, U., 1992. Risk Society: Towards a New Modernity. London: Sage Publications.

GIDDENS, A., 1996. Modernity and Self-Identity. Cambridge: Polity Press.

PETERSEN, A. \& LUPTON, D., 1996. The New Public Health: Health and Self in the Age of Risk. London: Sage Publications.

PHILIPS, A., 1999. Which Equalities Matter? Cambridge: Polity Press.

OLIVEIRA, D., 2001. Adolescent Woman Talk of HIVIAIDS Risk: Reconceptualizing Risky Sex - What Implications for Health Promotion? Ph.D. Thesis, London: Institute of Education, University of London. 
0 autor responde

The author replies

Mary Jane P. Spink
Inicio esta réplica, pontuando a importância da seção Debate dos Cadernos de Saúde Pública pela oportunidade de troca de idéias entre especialistas e por propiciar o contexto necessário para que os leitores possam exercer plenamente sua criatividade reflexiva, pondo a dialogar perspectivas e interpretações diversas sobre um mesmo fenômeno. Sigo, agradecendo com muita sinceridade aos doze debatedores. Sei que a tarefa de discutir um texto que aborda tão diversas questões não é fácil e pode até ter sido concomitantemente instigante e irritante. Entendo também, que a inversão lingüística proposta - onde linguagem é ação, é prática social e não apenas elo condutor ou mediação de sentidos - pode ter causado estranheza para alguns. Ao mesmo tempo em que agradeço o empenho de todos, declaro minha dificuldade de fazer jus a tão instigante coleção de comentários. Foram tantas as questões levantadas que múltiplos são os caminhos para o debate: a tarefa de responder ou comentar torna-se assim problemática tendo em vista o espaço destinado à réplica.

Difícil também a tarefa pelas novas conotações que assume o texto que norteia o debate nesses tempos atuais. É quase inoportuno falar de risco-aventura diante do espetáculo recente de insegurança frente ao terror organizado. Como concluiu Madel Luz em sua cuidadosa revisão das questões centrais à linha de argumento do artigo, as novas práticas sociais e discursivas sobre o risco talvez estejam sinalizando para a incapacidade da sociedade atual de lidar com seus riscos mais evidentes: a dissolução das instituições sociais, a enorme concentração de riqueza nas mãos de poucos, a crescente exclusão social (no interior das nações, entre nações, entre blocos de nações) enfim, a fragilidade da economia mundial. É significativo, nessa perspectiva, que a temática da exclusão social, associada aos processos de transformação da sociedade disciplinar em sociedade de risco, tenha sido um elo comum a tantos comentários.

Buscando atentar para a diversidade de aspectos abordados pelos debatedores, retomo os objetivos e a linha de argumento do texto em discussão. Tratava-se, antes de tudo, de uma reflexão sobre os processos de sociabilidade na contemporaneidade, sendo risco tomado como um foco conveniente para pensar as transformações que vêm ocorrendo nas formas de governamentalidade. É pertinente, assim, o pedido de esclarecimento de Edinilsa Ramos da Silva sobre o uso da partícula na como elo de ligação, no título, entre risco como metáfora e modernidade. Pertinente até porque alguns debatedores entenderam que eu estava propondo risco como metáfora da modernidade. Usei a partícula na por entender que outras metáforas podem expressar aspectos distintos da contemporaneidade - isso que Luis David Castiel denominou de "nossos tempos labirínticos", caracterizado pela produção de novas e engenhosas tecnologias e correspondente aceleração das trocas econômicas, das estratégias de comunicação, da di luição de matrizes identitárias e pelo clima generalizado de ambigüidade quanto às perspectivas de sentido. Não se trata, portanto, de pensar risco-aventura como plot de uma meta-narrativa sobre a tardo-modernidade, como interpretou Maria Helena Cardoso. As meta-narrativas são pouco adequadas a esses tempos labirínticos.

Sendo o foco da reflexão as transformações nos processos de governamentalidade, a tese sustentada implica tanto na narrativa histórica (para falar da passagem da sociedade disciplinar para a de risco e o papel da noção risco nesse processo) como na busca de compreensão das possibilidades de produção de sentido sobre os riscos na vida cotidiana. Essa proposta, nomeada por José Ricardo Ayres, de "tese da transformação", traz em seu bojo, como aponta o autor, tanto a ruptura das "condições de validade no horizonte normativo da modernidade", como novas formas de sensibilidades sociais diante do que Ayres denominou de "meiohostil" (a imponderabilidade dos riscos manufaturados). Pergunta ele se não se trataria de novas formas adaptativas no enquadre do "bom e velho darwinismo social". É possível que assim o seja para alguns neodarwinistas (Archer, 2001), mas não creio que o determinismo implicado nessa proposta seja adequado às vicissitudes dos processos de produção de sentidos em que se enquadra esta reflexão sobre o risco. Concordo, entretanto, com o autor - até por ser ela intrínseca aos processos exacerbados de individualização nessa modernidade tardia - que se trata sim de disciplina, embora de outro tipo. Concordo, ainda, que sendo menos visível (até porque vivida de forma mais solitária), mais difícil fica rebelar-se contra ela.

Nessa mesma direção procedem as observações feitas por Simone Monteiro \& Elizabeth 
Moreira, a partir da leitura de Deleuze (1992), sobre a transformação da sociedade disciplinar em sociedade de controle, onde o moldeé substituído pela modulação, sendo a informação o modulador fundante dos processos de gestão. É rica a observação e, se nesse enquadre, a informação é o modulador essencial dos processos de gestão, então o acesso à informação passa a ser aspecto central para entender não apenas os discursos contemporâneos sobre risco, mas também os novos processos de exclusão.

Ainda nessa direção, até porque pertinente à metáfora orientacional discutida por Luis David Castiel, vale a indagação da sustentabilidade da reflexão sobre risco-aventura no "lado debaixo" do Equador, preocupação verbalizada também por Edinilsa Ramos da Silva. Trata-se de questão que pede um debate mais aprofundado, impossível de ser feito no espaço destinado a esta réplica. Mas, muito sucintamente, sendo a circulação de repertórios interpretativos cada vez mais alicerçada na "ordem social da imagem mediática", tomando de empréstimo a expressão utilizada por Maria Helena Cardoso, seu potencial de sentido extrapola o espaço geograficamente pensado. Entretanto não deixa de ser, como propõe Castiel, "um ponto de vista acentuadamente marcado pelos signos do acesso aos mercados e da parti ci pação nos processos consumidores".

Retoma-se, dessa maneira, a temática da exclusão apontada por tantos dos comentaristas. Com certeza, concordando com Silvana Weller, os novos discursos do risco podem constituir uma nova modalidade de encobrimento das iniqüidades sociais já que, ao "equiparar lo ine qui parable", encobre variações de opção dos diferentes grupos humanos. Nessa perspectiva, vale a pergunta colocada pela autora sobre as “futuras derivações do interjogo do risco-aventura e a realidade material de milhões de pessoas que hoje parecem si mplesmente viver 'em perigo'".

Ainda com relação ao acesso às mensagens mediáticas, vários debatedores apontam como problema que os sentidos do risco são sempre socialmente situados. Na perspectiva discursiva, os sentidos são certamente produzidos em contextos históricos e culturais por meio de processos de interanimação dialógica os quais fazem circular, no aqui-e-agora, repertórios de tempos históricos diversos, matizados pelas experiências do tempo vivido (Spink e Medrado, 1999). Essa relação entre posi ções desujeito e sentidos do risco é objeto de pesquisa ora em andamento (Spink, 1999). Não era, porém, o foco da reflexão proposta no texto em debate. Assim, embora familiarizada com as teorizações de Thompson, Wildavsky e da própria Mary Douglas, também as atitudes frente ao risco decorrentes de diferentes projetos de modernidade - a oportunidade por mim perdida, segundo Carlos Machado - não constituíam foco da discussão travada no texto em debate. Digase de passagem, que a abordagem em questão, por seu teor estruturalista, dificilmente poderia ser compatibilizada com a perspectiva discursiva que busca na linguagem dos riscos as possibilidades de produção de sentidos, sempre fluídas e situadas nos micro-espaços de interanimação dialógica, e as posições de sujeito disponíveis na ótica dos processos de governamentalidade.

Embora a Saúde Pública - e mais especificamente os programas de prevenção à AIDS constituíram o ponto de partida para as pesquisas que venho desenvolvendo desde 1997 sobre a temática risco emodernidade tardia, as possibilidades de ressignificação do risco nos trabalhos de educação em saúde não constituiram foco específico de reflexão do artigo em pauta. Para além das "cobranças" ou frustrações pela ausência de reflexão específica sobre essa temática, vários debatedores preencheram ou deram pistas de possíveis caminhos para aprofundamento da questão. A eles sou agradecida. Assim, Rita Barata, posicionando-se estritamente como uma "praticante da Epidemiologia", problematiza o texto a partir da contraposição da assepsia conceitual do risco epidemiológico com a "explosão polissêmica" do "deslizamento" da reflexão para a linguagem em uso no cotidiano. Sem disputar que os gêneros de fala de diferentes campos são distintos, pontuo apenas, que os valores adentram a linguagem pelo uso que se faz dela. Assim, a própria autora acaba por afirmar - em sua conclusão - que "a complexi dade e os aspectos contraditórios inerentes à delimitação e cálculo dos riscos repercutem fortemente nas formas de percepção dos riscos pela população, etambém nas possíveis propostas de gestão dos riscos seja pela comunidade de especialistas seja pel os próprios indivíduos".

Outras comentaristas buscaram levar suas reações ao texto para arenas diversas de atuação em Saúde Pública. Por exemplo, Maria Lucia da Silveira considerou que o texto permite avançar na compreensão dos motivos que determinam o paradoxo da "distância intransponível entre o saber e o fazer". Levando-o a passear pelas experiências do cotidiano, propõe uma profusão de perguntas dirigidas ao campo da Saúde Pública (ou assim o interpretei) mais do que especificamente a mim. Edinilsa Ramos de Souza faz um exercício reflexivo sobre risco 
e jovens vítimas de violência, refletindo sobre as diferenças entre assumir riscos como "atributo individual" e estar em risco como fruto da vulnerabilidade. Sandra Caponi, apoiada em Canguilhem, reflete sobre a dimensão da aventura na definição de saúde. Contrapondo riscos medicamente aceitáveis e formas corrompidas de risco, coloca a instigante questão da possível diluição de fronteiras entre riscos socialmente desejáveis e os que a Saúde Pública historicamente considera como "não aceitáveis", a partir do trabalho de redução de danos na AIDS.

Já Dora Lúcia de Oliveira, familiarizada com a literatura sobre risco e modernidade, identifica-se com a posição por mim assumida e alerta que as "teses sobre a diversi dade semântica, sobre lógi cas eracionalidades do risco (...) ainda são estranhas aos paradigmas da saúde pública". Anuncia possibilidades de incorporação desta linha de reflexão citando autores e pesquisas recentes - inclusive sua recente tese de doutorado.

Mesclam-se assim, interpretações diversas do texto em debate e seleção de diferentes aspectos, com reações mais pessimistas (quanto ao futuro, à exacerbação dos processos de exclusão, à forma que tomam os processos disciplinares na sociedade contemporânea) ou mais propositivas (como trabalhar com a positividade do risco na Saúde Pública) dependendo da ótica priorizada na discussão. Termino estas poucas considerações reafirmando a riqueza do exercício do debate para que, a despeito de quaisquer divergências teóricas, possamos “manter a conversação fluindo" (Rorty, 1979:370).

\section{Referências}

ARCHER, J., 2001. Evolution and behaviour. Psychologist, 14:414-419.

DELEUZE, G., 1992. Conversações. Rio de Janeiro: Editora 34

RORTY, R., 1994. A Filosofia e o Espel ho da Natureza. Rio de Janeiro: Relume-Dumará.

SPINK, M. J. P., 1999. Risco elncerteza na Sociedade Contemporânea: Vivendo na Sociedade de Risco. Projeto Integrado. São Paulo: Conselho Nacional de Desenvolvimento Científico e Tecnológico. (mimeo.)

SPINK, M. J. P. \& MEDRADO, B., 1999. Produção de sentido no cotidiano: Uma abordagem teóricometodológica para análise das práticas discursivas. In: Práticas Discursi vas e Produção de Sentidos no Coti diano: Aproxi mações Teóricas e Metodológicas (M. J. P. Spink, org.), pp. 41-61, São Paulo: Cortez Editora. 